\title{
KONTROWERSJA WOKÓE ANNAT PAPIESKICH W POLSCE
}

Kościół dla osiągania swych celów duchowych, nadprzyrodzonych, ze swej natury potrzebował zawsze i potrzebuje środków czysto doczesnych, materialnych. Stąd też od zarania dziejów towarzyszy Kościołowi w jego zbawczej działalności dostosowany do okoliczności czasu oraz miejsca system prawno-ekonomiczny. Pewne elementy tego systemu, ze względu na zmieniające się uwarunkowania czasu, zupełnie już dzisiaj zanikły. Niektóre z nich zasługują na bliższe naświetlenie, dają bowiem pełniejszy obraz działania Mistycznego Ciała Chrystusa w perspektywie minionego czasu. Stanowią także bodziec do szukania innych rozwiązań w działalności zbawczej Kościoła na dzisiaj. Do takich zagadnień zdają się należeć annaty papieskie.

Prawo Kościoła do posiadania środków doczesnych dla prowadzenia misji zbawczej oraz administrowania nimi, jest prawem wrodzonym, własnym, niezależnym ${ }^{1}$. Praktycznie prawo to realizują poszczególne instytucje kościelne, na czele ze Stolicą Apostolską, wywodzącą się wprost z ustanowienia boskiego. Stolica Apostolska, jako zwierzchnia instytucja kościelna, ma swoje szczególne przeznaczenie; kieruje całą nawą Kościoła, porządkuje całą jego strukturę — wewnętrzną i zewnętrzną; ustawia jego pozycję na zewnątrz do społeczności ludzkiej, wśród której istnieje. Papieże byli zawsze świadomi tych najwyższych praw oraz powinności. Na różne też sposoby rozwiązywali system gromadzenia środków dla potrzeb Stolicy Apostolskiej oraz Kurii Rzymskiej. Począwszy od późnego średniowiecza w systemie tym rozwinął się i na długo ustabilizował, między innymi, zwyczaj pobierania tak zwanych annat.

Annaty papieskie w sensie najbardziej ogólnym były to świadczenia duchownych na rzecz skarbu Stolicy Apostolskiej z okazji otrzymywania beneficjów $\mathrm{z}$ rąk papieża. Trzeba bowiem pamiętać, że w omawianym okresie do Biskupa Rzymskiego należało nie tylko nadawanie wszystkich bez wyjątku wyższych

\footnotetext{
* W przypisach zastosowano następujące skróty:

HL - C. Hefele, D. H. Leclercq, Histoire des conciles, t. 7-8, Paris 1916-1918.

MPV -Monumenta Poloniae Vaticana, ed. J. P taśnik, t. 1-, Kraków $1913-$.

RTK - „Roczniki Teologiczno-Kanoniczne” Katolickiego Uniwersytetu Lubelskiego.

StPPP - Starodawne prawa polskiego pomniki, t. 1-, Kraków 1856-

VMPL - Vetera monumenta Poloniae et Lithuaniae gentiumque finitimorum historiam illustrantia, ed. A. The in e r, t. 1-2, Romae 1860-1861.

${ }^{1}$ Tę deklarację prawa boskiego przekazuje cała tradycja kanonistyczna włącznie do ostatniego Kodeksu prawa kanonicznego z r. 1983 (zob. kan. 1254).
} 
stanowisk kościelnych, jak biskupstwa czy opactwa, lecz z tak zwanej rezerwacji wiele niższych beneficjów, jak prebendy kanonickie, parafie, itd. Tak więc z okazji tego nadawania stanowisk Stolica Apostolska rezerwowała sobie także płatność annat przez tych, którzy je otrzymywali. Pobieranie annat, oparte na specjalnym ustawodawstwie papieskim stworzyło cztery kategorie tych świadczeń: (1) annaty od posiadaczy beneficjów niższych (prebendy kanonickie, prafie itp.), określane tym właśnie słowem; (2) annaty od posiadaczy beneficjów wyższych (biskupstwa, opactwa), które się dzieliły na „serwicja wspólne” („servitia communia”) i ,serwicja zmniejszone” (,servitia minuta”); (3) „quindenia", tj. annaty uiszczane co piętnaście lat $\mathrm{z}$ beneficjów niższych inkorporowanych $^{2}$.

W literaturze zagranicznej poświęcono już sporo uwagi problematyce annatowej, gdy idzie o tę praktykę w innych krajach ${ }^{3}$. W Polsce, nie licząc encyklopedycznych haseł, ukazało się dotąd kilka artykułów poświęconych praktyce pobierania annat w naszym kraju, z naświetleniem ich w nieco szerszym kontekście, ogólnokościelnym ${ }^{4}$. Nie opracowano jednak dotąd interesującej kontrowersji, jaką wzbudziła ta praktyka u współczesnych sobie faktorów historycznych. W świetle sporu o annaty papieskie ujawniły się bliżej elementy tworzące ich treść oraz motywy eklezjalne, które je uzasadniały. Podejmując ten temat $\mathrm{w}$ odniesieniu do Polski, przedstawimy najpierw czynniki zwalczające annaty papieskie, w drugiej zaś części artykułu ich obronę. Po obydwu stronach znajdują się ludzie, którzy z różnych pozycji prawnych występowali w obronie tych świadczeń finansowych bądź też je podważali. Ich zespoły po obydwu stronach można podzielić na dwie różne jakościowo grupy, a mianowicie pisarzy kościelnych czy politycznych oraz przedstawicieli s połe czeńst wa i wła dzy, bądź to kościelnej bądź świeckiej. Chronologicznie pierwsza się pojawiła opozycja annatowa, dlatego będzie omówiona na pierwszym miejscu. Przy czym poglądy pisarzy odgrywały tu rolę teoretycznych przesłanek dla podejmowania działań praktycznych przez czynniki społeczno-autorytatywne. Stąd damy im pierwszeństwo przed tymi drugimi. W akcji zaś obrony annat niewątpliwie główną rolę odegrał czynnik praktyczny. Dlatego też w tym zakresie bardziej uzasadniony będzie porządek odwrot-

${ }^{2}$ J. D u dzia k, U źródet tworzenia się annat papieskich, RTK 10: 1963 z. 4 s. 27; tenże, Annaty, [w:] Encyklopedia katolicka, t. 1, Lublin 1973, kol. 630. Annaty pojawiły się w systemie finansowym Stolicy Apostolskiej w drugiej połowie XIII w., a ukształtowały się w regularną praktykę w pierwszej połowie XIV w. (tenże, Ptatnicy i ptatności annat papieskich w Polsce, RTK 9:1962 z. 1 s. 41).

${ }^{3}$ Np. J. P. Kirs ch, Die päpstlichen Annaten in Deutschland während des XIV. Jahrhunderts, Paderborn 1903; F. Mah on de Mon agh a n, Etude sur les annates, Paris 1909; A. Puglie se, Annate e mezzannate nel diritto canonico, Milano 1939; F. B a ix, La Chambre Apostolique et les „Libri Annatarum” de Martin V (1417-1431), Bruxelles-Rome 1947.

${ }^{4}$ Zob. wyżej przypis 2. Nadto: J. D u d zi a k, Annaty papieskie w świetle narastających przepisów prawnych ze szczególnym uwzględnieniem Polski, RTK 12:1965 z. 5 s. 104-130; tenże, Rozwój historyczny świadczeń annatowych w Polsce, RTK 13:1966 z. 5 s. 29-55; tenże, Pobieranie annat papieskich, RTK 14:1967 z. 5 s. $62-97$. 
ny, a mianowicie omówienie czynników społeczeństwa i władzy przed poglądami pisarzy.

\section{ZWALCZANIE ANNAT PAPIESKICH}

Opozycja przeciw annatom papieskim zrodziła się i działała na podłożu ogólniejszych kierunków, które nurtowały Europę od XV w. Oto z dążeń do przeprowadzenia powszechnie oczekiwanej reformy w Kościele zrodziły się na soborach w Pizie, Konstancji i Bazylei radykalne idee koncyliarystyczne. $\mathrm{Z}$ nich to bezpośrednio wyrosły silne ataki na rzekomo zbyt uprzywilejowaną praktykę Kurii papieskiej pobierania annat ${ }^{5}$. W ślad za koncyliaryzmem poszly koncepcje gallikanizmu we Francji oraz febronianizmu w Niemczech, które stworzyły nowy klimat ideowy także poza granicami wymienionych krajów. Klimat ten sprzyjał wszelkiemu ograniczaniu kompetencji i wplywów Stolicy Apostolskiej, włącznie z jej prawem do annat. We Francji dołączył się ponadto skrajny absolutyzm władzy królewskiej, dążący do wykluczenia wszelkiej obcej ingerencji oraz ekonomiczny kierunek merkantylizmu, opierający gospodarkę narodową na imporcie złota oraz monecie, a zabraniający ich wywozu ${ }^{6}$. Wraz z humanizmem oraz reformacją owe liberalne kierunki doznały spotęgowania oraz usankcjonowania w szerokich kręgach świadomości społecznej, so stworzyło jeszcze podatniejszy grunt dla wystąpień niechętnych konstytucyjnym prawom Kościoła. Sama reformacja zaś wniosła do tej świadomości mocny posiew nieżyczliwości w stosunku do papiestwa ${ }^{7}$.

Na tym samym podłożu społeczno-ideowym zrodziła się oraz działała opozycja annatowa w Polsce. Niektóre jej motywy przyjmowały się u nas w zależności od układu stosunków krajowych. Idee koncyliarne zyskały sobie u nas wielu zwolenników od XV w. Przeszczepiano tu teorie gallikańskie i febroniańskie, wyrosłe zaś z humanizmu liberalne kierunki filozoficzno-społeczne zyskały nawet pewne wzbogacenie w twórczości St. Orzechowskiego czy Frycza Modrzewskiego $^{8}$. Jednakże momentami, które szczególnie zaciążyły na wystąpieniach przeciwannatowych w Polsce i które trzeba nazwać bardziej typowymi, specyficznymi dla naszego kraju, były potrzeby skarbu państwa oraz nacis-

5 B. Kumor, Historia Kościoła. Cz. 4: Jesień kościelnego średniowiecza, Lublin 1978, s. $67-71$.

${ }^{6}$ F. Mahon de Monaghan, jw., s. 171-173.

${ }^{7}$ Geschichte der Kirche. Bd 3: Reformation und Gegenreformation, hrsg. von A. G. We ile r, Nijmegen 1965 , s. 26-45.

${ }^{8}$ P. L. Mess nard, L'essor de la philosophie politique au $16^{e}$ siêcle, Paris 1951, s. 407-408. 
ki ze strony propagandy innowierców ${ }^{9}$. Problem łatania budżetu koronnego był w Polsce przedrozbiorowej prawie stale żywotny, na skutek wydatków związanych z ciągłymi wojnami i wynikłymi stąd zniszczeniami kraju. Toteż ten zwłaszcza motyw przewijał się poprzez prawie wszystkie wystąpienia przeciwannatowe u nas.

\section{PIŚMIENNICTWO PRZECIWANNATOWE}

Reformistyczno-radykalne piśmiennictwo, zawierające także krytykę annat, uprawiali w Kościele liczni teologowie i pisarze na zachodzie Europy już od końca XIV w. Dość by tu wspomnieć słynnego teologa Sorbony Jana Gersona (1363-1429) ${ }^{10}$ jako jednego z pierwszych, czy też innych zwolenników gallikanizmu i febronianizmu, na czele z samym Mikołajem Hontheimem, czyli Febroniuszem (1701-1790) ${ }^{11}$, jako jednym z ostatnich. Piśmiennicza działalność przeciwannatowa, prowadzona na zachodzie Europy, znalazła znaczny oddźwięk także w Polsce. Krytyczny wyraz wobec praktyki annatowej dawało w naszym kraju wielu mistrzów pióra, uzasadniając swe poglądy w tym względzie bądź to potrzebą reformy Kościoła, będź zmiany ustroju państwa. Poza Janem Ostrorogiem, który był człowiekiem świeckim i opierał się na przesłankach czysto politycznych, wszyscy inni byli duchownymi i mieli na celu poprawę stosunków kościelnych w ogóle. Wywodzili się zaś ze środowiska Uniwersytetu Jagiellońskiego, będącego ogniskiem nauki polskiej i jako jego przedstawiciele wywierali duży wpływ na społeczeństwo, a niektórzy byli znani szeroko za granicą.

Pierwszym tej miary pisarzem był Mateusz z Krakowa ${ }^{12}$. Pośredniej krytyki annat należy się dopatrywać u tego autora w jego dwóch traktatach, a mianowicie: Speculum aureum oraz De squaloribus Curiae Romanae. Piętnuje on bowiem w nich całokształt papieskiego systemu finansowego w $14 \mathrm{w}$. Należy zauważyć, że wystąpienia Mateusza z Krakowa miały charakter nie tyle naukowy, co publicystyczno-dyskusyjny.

W sposób bardziej gruntowny i wyczerpujący wypowiedział się na temat

\footnotetext{
${ }^{9}$ Jeśli idzie o wątek pochodzący ze strony propagandy innowierców, to daje temu wyraz jeden z nuncjuszy papieskich w Polsce, który w swoim sprawozdaniu do Kurii rzymskiej z 7 marca 1550 r. napisał, że na swoich zebraniach heretycy domagali się odmówienia annat Rzymowi, a przeznaczenia ich na obronę Rzeczypospolitej (zob. VMPL 3 s. 179 n.).

10 Joannis Ge rs o n, Consideratio VII, [w:] tegoż, Opera, pars I, Parisiis 1521, fol. 28; L. S ala m bie r, Gerson Jean de Chartier, [w:] Dictionnaire de theologie catholique, ed. A. V a c a n t, E. Mangenot, E. A mann, t. 6/1, Paris 1924, col. 1313-1317.

${ }_{11}$ Iustini Fe b r o $\mathrm{i} \mathrm{i}$, De statu Ecclesiae et de legitima potestate Romani Pontificis liber singularis, Bullioni 1763, s. 468 (cap. VIII § 5).

12 Urodzil się około roku 1335 w Krakowie. Wykształcony najpierw w sztukach wyzwolonych, odbył następnie studia teologiczne i został mistrzem oraz profesorem Akademii Krakowskiej. Na kilka lat przed śmiercią otrzymał biskupstwo wormackie, gdzie zmarl w r. 1410 (T. S o m m e rla nd, Mathaeus von Krakau, Halle 1891, s. 18, 20).
} 
annat Paweł Włodkowic, zwany też Pawłem z Brudzenia ${ }^{13}$. Napisał on dwa traktaty: De annatis camerae apostolicae solvendis; pierwszy w drodze na sobór do Konstancji, dokąd udawał się z delegacją w 1415 r., drugi zaś podczas trwania soboru lub zaraz po jego zakończeniu w $1418 \mathrm{r} .{ }^{14}$ Obydwa traktaty mają charakter rozpraw analityczno-naukowych, w których autor określa ściśle pojęcia, stawia twierdzenia, rozwija argumenty. Zasadnicze znaczenie ma traktat pierwszy. Został bowiem napisany przed przybyciem P. Włodkowica do Konstancji, odzwierciedla więc wiernie nie tylko jego osobiste zapatrywania na to zagadnienie, lecz środowiska Akademii Krakowskiej. Należy tu od razu zauważyć, że atmosfera Akademii, owiana duchem reformy Kościoła, była wówczas przepojona zasadami koncyliarnymi. Otóż miarą znaczenia, jakie w ówczesnym, polskim programie reform wysuniętym do Konstancji odgrywały annaty jest fakt, że zajęły one pierwsze miejsce wśród sześciu punktów tego programu, umieszczonych przez $\mathrm{P}$. Włodkowica we wstępie traktatu. $\mathrm{Z}$ rozwinięcia wymienionego pierwszego punktu powstały właśnie traktaty o annatach. Dalsza część rozprawy P. Włodkowica, rozwijająca zapowiedziane punkty programu reform, nie jest do dzisiaj znana ${ }^{15}$. Pierwszą część annatowych rozważań, czyli jak gdyby traktat pierwszy, P. Włodkowic przedłożył soborowi w Konstancji. Jego wywody nie znalazły tam jednak akceptacji, co autor otwarcie przyznał, dlatego też podjął ponowną analizę tej problematyki, pisząc jak gdyby traktat drugi ${ }^{16}$. W gruncie rzeczy doszedł tu do takich samych wniosków końcowych, jakie postawił w części pierwszej, dając im jeszcze głębsze uzasadnienie.

Według poglądów P. Włodkowica, papież ma w zasadzie prawo rezerwować sobie pierwszoròczne dochody, czyli annaty ze wszystkich beneficjów kościelnych, jako ich najwyższy rozdawca. Jednakże z moralnego punktu widzenia powinien to czynić tylko ze słusznej przyczyny, która ze swej natury nie powinna być stała, lecz przejściowa ${ }^{17}$. P. Włodkowic wyraził natomiast zastrzeżenie co do formy pobierania annat, rozróżniając trzy możliwe sposoby oraz podając ocenę każdego $\mathrm{z}$ nich. Pierwszym sposobem było odbieranie zobowiązania w Kamerze Apostolskiej od kandydata na urząd kościelny, że przekaże on swoje dochody jednoroczne najpóźniej do roku od objęcia beneficjum w posiadanie. Drugi sposób polegał na domaganiu się od beneficjata, by tytułem annat złożył gotową kwotę od razu przy akcie prowizji. Trzeci wreszcie sposób wyrażał się w uzależnieniu wydania dokumentu prowizyjnego od rzeczywistej

${ }^{13}$ Urodzil się około roku 1370. Data jego śmierci przypada na lata 1435-1443. Zdobywszy wykształcenie w Pradze i Padwie jako doktor dekretałów został profesorem prawa na Akademii Krakowskiej. Był również kanonikiem-kustoszem kapituły krakowskiej (T. B r zo s tow s ki , Pawet Wtodkowic, Warszawa 1954, s. 46-48, 51).

${ }^{14}$ L. Eh rlich, Pawet Wtodkowic i Stanistaw ze Skarbimierza, Warszawa 1954, s. 50.

${ }^{15}$ StPPP 5 s. 299-304; T. B rzos tow sk i, jw., s. 58.

16 Tamże, s. 61.

17 „Quia istae duae conclusiones [...] per dominos meos hic de concilio [...] recepta non fuerunt, ideo transferendo me ad sententias altiores [...] scribo ut sequitur" (StPPP 5 s. 305). 
wpłaty annat ${ }^{18}$. Przy wartościowaniu każdego $\mathrm{z}$ wymienionych sposobów, P. Włodkowic wyraził przekonanie, że pierwszy z nich jest dopuszczalny (,tolerabile”), drugi trzeba zakwestionować („,detestabile”), trzeci wreszcie zasługuje na pełne odrzucenie („damnabile”) ${ }^{19}$. W dosyć obszernym dowodzeniu rektor Uniwersytetu Krakowskiego posługuje się wnikliwą spekulacją filozoficzno-prawną. Dopuszczalność pierwszej formy ściągania annat była jego zdaniem zrozumiała zarówno ze strony papieża jak i beneficjata. Papież bowiem jako ogólny szafarz stanowisk kościelnych jest uprawniony do zastrzegania sobie pewnej części ich dochodów, o ile zachodzi słuszna przyczyna ${ }^{20}$. Konieczność słusznej przyczyny wynika stąd, że papież nie jest ani właścicielem beneficjów (nie posiada nad nimi „dominium proprium”), ani też ich użytkownikiem (nie posiada ich „dominium utile”), lecz jako zastępca Boga („vicarius Christi”) jest ich szafarzem, rozdawcą („dispensator”). W pełnieniu zaś roli szafarza-zastępcy powinny mu towarzyszyć wierność oraz roztropność zgodnie z nakazem Ewangelii: „Fidelis servus et prudens”. Te zaś przymioty domagają się, ażeby sobie nie przywłaszczać dochodów beneficjalnych jak tylko w wypadku konieczności lub użyteczności publicznej, czyli innymi słowy w wypadku słusznej przyczyny ${ }^{21}$. Ze strony beneficjata ta forma uiszczania dochodów jest również dopuszczalna, gdyż obciążają one nie jego osobę, lecz beneficjum, które przechodzi z rąk do rąk. Swiadcząc zatem annaty, nie płaci on ze swojego, lecz z rzeczy, która się należy papieżowi z tytułu rezerwacji ${ }^{22}$.

Kwestionowany przez siebie drugi sposób ściągania annat, P. Włodkowic uzasadniał na drodze analizy prawnej samej natury rezerwacji. Otóż rezerwacja pierwszorocznych dochodów rodziła, jego zdaniem, sama z siebie zobowiązanie rzeczowe, nie zaś osobowe. Wobec tego ten tylko był obowiązany je świadczyć, który je faktycznie posiadł i tam gdzie je posiadł ${ }^{23}$. Z tak pojętą naturą rezerwacji stało w sprzeczności uprzednie świadczenie annat przy prowizji beneficjów, gdyż: przekształcało zobowiązanie rzeczowe w osobowe, powodo-

${ }^{18},[. .$.$] papa reservavit sibi fructus medios [czyli annaty] primi anni omnium beneficiorum, qu-$ ibus ipse providet [...] Dico primum tolerabile ratione papae, quia est dispensator generalis omnium beneficiorum ecclesiasticorum et ex iusta causa reservare sibi potuit, licet cessante iusta causa, quae nec est continua nec perpetua, sedem apostolicam non decet talium fructuum reservatio" (tamże).

19 Tamże, s. 299.

$20,[\ldots]$ et ex iusta causa reservare sibi potuit" (tamże).

21 "Est etiam tolerabile ex parte obligati [...] revera personae hoc onus non imponitur sed beneficio, quod transire debet cum onere suo, et ideo ex parte obligati potest esse licita" (tamże, s. 300).

22 „Pro quorum intelligentia clariori videnda sunt ista, quae natura reservationis continet [...] In primo datur intelligi, quod hoc debitum reservatorum fructuum et communium servitiorum est reale non autem debitum personale. Et ideo res fructum sequitur non personam unde nonnisi possessor rei ad illos tenetur [...] Qui autem fructus primi anni nondum percepit, vel etiam non possidet, non tenetur, perceptio enim fructuum est causa solutionis, qua cessante cessare debet solutio" (tamże, s. 301).

${ }_{23}$ "Cum autem talis mutatio dictae obligationis in realem et actualem solutionem iniquitatem continet eo, quod hic petitur plus re, plus tempore, plus loco, plus causa, contra naturam dictae reservationis" (tamże, s. 301). 
wało skutek przed powstaniem przyczyny, nie uwzględniało momentu czasu i miejsca, jako integralnych elementów wspomnianej obligacji rzeczowej24. Wzięła tu więc górę mentalność głębokiego teoretyka prawa dekretałów nad umysłowością praktyczną. Jak gdyby na marginesie tej części zagadnienia P. Włodkowic dodaje, że nie da się uzasadnić kilkakrotnego pobierania annat w ciągu tego samego roku, gdyby wakans beneficjum był wielokrotny, gdyż sprzeciwia się temu natura dochodów, które według przyrodzonego porządku rzeczy są jednorazowe ${ }^{25}$.

Bezzasadność trzeciego sposobu pobierania annat wynika z pojęcia symonii, która zdaniem P. Włodkowica leżałaby u jego podstaw. Na dowód zestawia on dokument prowizyjny z samym nadaniem beneficjum. Dokument ten stanowi, jego zdaniem, jeden $\mathrm{z}$ istotnych czynników prowizji, bez niego bowiem nie można było objąć w posiadanie stanowiska kościelnego. Jeżeli więc ten istotny, chociaż końcowy element prowizji byłby uwarunkowany od złożenia opłaty annatowej, to zachodziłby tu cichy kontrakt kupna i sprzedaży, który swoje piętno symoniackie wyciskałby na całym nadaniu stanowiska ${ }^{26}$. Postawiwszy tę formę pobierania annat na płaszczyźnie symonii, autor w dalszym toku wywodów zwalcza je argumentami wymierzonymi przeciwko symonii. Ten pogląd odpowiada ówczesnemu stanowi nauki prawa kanonicznego. Jednakże później w działaniach prawnych poczęto rozróżniać elementy formalne oraz merytoryczne. Dokumenty aktów prawnych nie stanowią ich czynników merytorycznych, wewnętrznych. Praktyka Kurii papieskiej wyprzedzała więc poglądy teoretyczne w dziedzinie kanonistyki.

Oceniając wywody P. Włodkowica wyrażone w traktatach annatowych, trzeba najogólniej stwierdzić, że cechuje je z jednej strony duch radykalizmu, właściwy ówczesnym koncyliarystom, z drugiej — żywiołowe pragnienie usunięcia przerostów, do jakich jego zdaniem doszło w kościelnym systemie finansowym $^{27}$.

Poglądy Pawła z Brudzenia na temat annat przejął teolog czeski Ma u ry cy Rwačk a z Pragi. Był on również przez jakiś czas związany z Akademią Krakowską, jako jej mistrz. W tym też charakterze posłował do Konstancji przy boku P. Włodkowica. W 1416 r. przedłożył on tam soborowi dwanaście swoich „konkluzji”, zmierzających do zwalczenia symonii, gdzie w nieco zmie-

\footnotetext{
${ }^{24} \mathrm{~W}$ oparciu o należący do istoty rezerwacji element miejsca, jak utrzymywał P. Włodkowic, występował także przeciwko świadczeniu annat na miejscu w Kurii papieskiej, co beneficjata narażało na dodatkowe koszty, lecz domagał się pobierania ich w kraju przez kolektorów (tamże). Było to zresztą u nas regułą, mającą tylko nieliczne wyjątki i to $\mathrm{z}$ winy beneficjatów, którzy nie uiścili na czas wpłaty kolektorom.

${ }^{25}$ "Est etiam contra naturam fructuum, quos natura non procreat nisi semel in anno" (tamże).

26 "Praeterea quamvis ex verbis contrahentium expresse non apparet, quod hic est emptio vel venditio, clare tamen constat ex effectibus, nam non datur provisio cum effectu, nisi fiat pecuniae realis solutio. Dico cum effectu, quia litterae non dantur per quos quos venitur ad effectum provisionis" (tamże, s. 302).

${ }^{27}$ Por. K. Mor a w s k i, Historya Uniwersytetu Jagiellońskiego, t. 1, Kraków 1900, s. 131.
} 
nionej formie wyraził Włodkowicowe poglądy annatowe. ${ }^{28}$

Następnym człowiekiem pióra, który w Polsce kształtował opinię o papieskich annatach, był J a k u b z P a r a d y ż a ${ }^{29}$. Spośród bogatej jego spuścizny pisarskiej na szczególniejszą uwagę zasługuje traktat De statu et officio ecclesiasticarum personarum, powstały w latach 1447 - 144930. Piętnując w nim nadużycia stanu duchownego na różnych szczeblach hierarchicznych, autor potrąca także o sprawę annat. Mianowicie w 34 rozdziale pierwszej części traktatu umieszcza tzw. „Canon Petri contra simoniacos”31. Zawiera on dziesięć konkluzji czyli twierdzeń, w których znajduje się wyjaśnienie symonii, potępienie jej we wszelkich postaciach oraz uzasadnienie tego potępienia. Konkluzja piąta odnosi się właśnie do annat. Mistrz z Paradyża podkreśla w niej, że także annaty miałyby charakter symonii, gdyby od ich zapłacenia uzależniano wydawanie bulii prowizyjnej po dokonanym już akcie nadania beneficjum ${ }^{32}$. W dowodzeniu swego stanowiska autor odwołuje się do pojęcia symonii, które jego zdaniem urzeczywistnia się w pełni we wspomnianej formie ściągania annat ${ }^{33}$. J. Fijałek zwraca uwagę, że traktat Paradyżanina nie jest oryginalny. Zwłaszcza w 34. rozdziale traktatu są jego zdaniem widoczne wpływy Maurycego Rwački z Pragi. Istotnie zachodzi pewne podobieństwo pomiędzy konkluzjami Maurycego oraz Paradyżanina. Jeżeli jednak idzie o sprawę samych annat, to Mistrz Jakub jest nieco łagodniejszy, gdyż do symoniackich praktyk zalicza tylko ten sposób ich pobierania, który polega na uwarunkowywaniu wydania bulli prowizyjnej od uiszczenia tych świadczeń. Natomiast Maurycy Rwačka jest o wiele skrajniejszy w swych annatowych poglądach, ponieważ za symonię uważa nawet odbieranie zobowiązań od kandydatów, że spłacą annaty po objęciu beneficjum w posiadanie, o ile od takiego zobowiązania jest uzależnione wydanie samej bulli ${ }^{34}$. Otóż trzeba zauważyć, że pod tym względem poglądy teologa czeskiego też nie są jego własne, lecz stanowią prawie dosłowne powtórzenie myśli z traktatu Pawła Włodkowica o annatach. Nie ma w tym zresztą nic dziwnego, gdy się ma w pamięci, że Maurycy był jednym z członków dele-

${ }^{28}$ W konkluzji piątej przyznaje on papieżowi prawo do annat, które w jego przekonaniu opiera się na prawie Bożym. W konkluzjach 11 i 12 piętnuje praktykę pobierania annat w gotowej kwocie i z góry przy prowizji stanowiska lub odbieranie nawet zobowiązań co do późniejszej płatności, gdy takie wpłacenie lub zobowiązanie jest warunkiem wydania bulli prowizyjnej; - zob. J. Fija le k, Mistrz Jakub z Paradyża i Uniwersytet Krakowski wokresie Soboru Bazylejskiego, t. 2, Kraków 1900, s. 242, 244, 246, 248.

29 Tamże, t. 1 s. 45,$66 ;$ t. 2 s. $86,114$.

30 Traktat ten został wydany drukiem przez Lydiusa w r. 1617, lecz wydanie to nie jest znane. Przechował się też w rękopisach. Omawiam go na podstawie cytowanego wyżej dzieła ks. Fijałka.

31 Takie ujęcie jest uzasadnione powołaniem się przez autora na słowa św. Piotra, wyrzeczone do Szymona Maga: „pecunia tua sit tibi in perditionem” (tamże, t. 2 s. 243).

32 „Arrestatio bullarum super solutionibus annatarum vel vacantiarum post factam provisionem est actus simoniacus" (tamże).

33 „Probatur ex premissis, quia est actus exterior a voluntate imperatus, includens estimationem simoniacam velut intrinsecum actum provisionis, que est quid spirituale pro temporalium solutione; ideo est simoniaca commutatio temporalis pro spirituali" (tamże).

34 Tamże, s. 248. 
gacji na sobór do Konstancji, w której tak wielką rolę odegrał Paweł z Brudzenia. Jakkolwiek więc Jakub z Paradyża jest zależny w swych poglądach na annaty od Maurycego z Pragi, a poprzez niego od P. Włodkowica, wyróżnia się jednak tym, że ostrze jego wystąpień przeciw tym świadczeniom jest już mocno przytępione. Ani bowiem nie kwestionuje samej zasadności annat, ani ich płacenia z góry w gotowej kwocie pieniężnej, ani podejmowania zobowiązań odnośnie do późniejszej ich płatności. Odrzuca jedynie uwarunkowanie wydawania bull prowizyjnych od faktycznych wpłat annatowych.

Oprócz omówionych pisarzy, którzy na gruncie polskim podejmowali piśmienniczą działalność przeciwannatową w ramach ogólniejszego programu reformy kościelnej, należy wspomnieć polskiego pisarza, który wystąpienie tego rodzaju podjął $\mathrm{z}$ pobudek bardziej polityczno-krajowych. Był nim Jan Ost r o róg, wojewoda poznański. Uchodzi on za pierwszego pisarza politycznego Polski epoki odrodzenia. Tytuł ten zdobył głównie przez napisanie w latach 1474-1477: Monumentum pro Reipublicae ordinatione ${ }^{35}$. Polski statysta kreśli w nim program polityczno-ustrojowych reform w państwie. Wysuwając, jako koncepcję ogólną, postulat niezależności króla od czynników zewnętrznych, Ostroróg określa także zasady jego stosunku do Stolicy Apostolskiej. Nie pomija przy tym kwestii annat, lecz poświęca im VIII oraz IX rozdział swego Monumentum. W rozdziale VIII Ostroróg omawia przyczyny, dla których zostały wprowadzone annaty, podważa ich zasadność oraz domaga się ich zniesienia. Nie przebiera przy tym w słowach, lecz jest pełen sarkazmu i krytycznego odnoszenia się do Stolicy Apostolskiej. Chociaż z jednej strony nazywa to świadczenie „pensio sacra sive annata”, to z drugiej oburza się na jego niegodziwość (,dolendum[...] et inhumandum facinus”). Stwierdza, że jest to praktyka wymyślona przez Włochów „dla zaspokojenia żądzy chciwości”. Wysuwa postulat zniesienia annat, gdyż „godzą one w suwerenność Królestwa Polskiego" oraz „nie licują z ojcowskim urzędem papieża”" ${ }^{36}$. W rozdziale IX autor Monumentum jak gdyby się opamiętał, odrzuca już swój napastliwy ton, lecz w sposób spokojny i rzeczowy domaga się, ażeby papież, który ma pełne prawo pobierania annat $w$ innych krajach, nie ściągał ich z Polski, lecz pozostawił na potrzeby kraju. Polska bowiem powstrzymując napór potęg tureckich i tatarskich, chroni nie tylko siebie, lecz stoi na straży wolności wszystkich krajów zachodnich. Pociąga to za sobą wielkie koszty związane z wojnami oraz odbudowaniem wynikłych stąd zniszczeń. Kraj popada w ubóstwo do tego stopnia, że nawet utrzymanie wewnętrznego spokoju staje się częstokroć niemożliwe ${ }^{37}$. A zatem J. Ostroróg nie odmawia ostatecznie papieżowi prawa do pobierania

${ }^{35} \mathrm{Z}$. Ka czmarczy k, B. Leśnodorski, Historia państwa i prawa Polski od potowy $X V w$. do r. 1795, red. J. B a rdu ch, Warszawa 1957, s. 91; Historia Polski, red. H. Łow miań s ki, t. 1/2, Warszawa 1957 , s. 168.

${ }^{36}$ StPPP 5 s. $120 \mathrm{n}$.

${ }^{37}$ Tamże, s. 121. 
annat, wysuwa jednak postulat zaniechania tego poboru w Polsce z przyczyn polityczno-ekonomicznych. W ten sposób bilans wystąpień przeciwannatowych Ostroroga jest bardziej radykalny w formie, tj. doborze słów, niż w samej rzeczy ${ }^{38}$.

Począwszy od XVI w. nie podjął już krytyki annat żaden $\mathrm{z}$ wybitniejszych pisarzy polskich ${ }^{39}$. Nie znajdujemy tego zagadnienia ani u Frycza Modrzewskiego (1503-1572), ani St. Orzechowskiego $(1515-1567)^{40}$. Zagadnienia annat papieskich nie uwzględniają również najwybitniejsi przedstawiciele politycznej literatury XVIII w., jak Hugo Kołłątaj (1750-1812) czy Stanisław Staszic (1755-1826) ${ }^{41}$. Jak z powyższego widać, pisarska działalność przeciwannatowa ogranicza się u nas głównie do XV w. Prowadzono ją już to z pozycji ogólnoreformistycznych, już też polityczno-państwowych. Od XVI stulecia ten opozycyjny sposób pisania o annatach zanika, zarówno w twórczości filozoficzno-politycznej, jak i reformistyczno-kościelnej. Jedną z przyczyn tego zjawiska, jeśli nie główną, był niewątpliwie fakt, że w XVI w. zaczęły u nas działać czynniki, które dążyły do praktycznego uchylenia świadczeń annatowych. Można zatem powiedzieć, że piśmiennictwo jak gdyby odegrało już swoją rolę, tj. przygotowało grunt do działalności praktycznej.

\section{ZWALCZANIE ANNAT \\ PO STRONIE DUCHOWIEŃSTWA, KRÓLA I SZLACHTY}

Najsilniej zaangażowanym krajem w nastrojach reformistycznych oraz przeciwannatowych była Francja. Tak było przed soborem w Konstancji (1414 1418), tak też pozostało potem. Pomimo konkordatu, w którym nacja francuska zobowiązała się w Konstancji w r. 1418 do respektowania praktyki annatowej, Francuzi odgrywali główną rolę w Bazylei, gdzie wraz z radykalizu-

38 Por. A. Re m bows ki, Jan Ostroróg i jego memoryat o naprawie Rzeczypospolitej, Warszawa 1884 , s. 89.

${ }^{39}$ Można by tu odnotować jakieś odosobnione i mniejszej wagi wzmianki z tej dziedziny. Tak np. Mikołaj Rej z Nagłowic (1505-1568) opowiadał się w swoim Zwierzyńcu za pozostawieniem annat na potrzeby kraju, twierdząc że nie idą one w Rzymie na dobre cele. Lakoniczną wypowiedź, domagającą się przeznaczenia annat na potrzeby Królestwa Polskiego, pełniącego misję przedmurza chrześcijaństwa, znajdujemy też u jednego z osiemnastowiecznych polityków - M. Zalaszowskiego, w jego: Ius Regni Poloniae ex statutis et constitutionibus eiusdem regni et M. D. L. collectum, t. 1, Varsoviae 1741, s. 30.

${ }^{40}$ Wydaje się, że dla twórczości tych pisarzy, mającej charakter ogólniejszy, annaty stanowiły zbyt szczegółowe zagadnienie.

${ }_{41}$ Hugo Kollątaj, kreśląc program politycznej naprawy państwa w XVIII w., nie wspomina o żadnych świadczeniach na rzecz Rzymu. Mógł to zaś uczynić, układając np. projekt finansowych podstaw dla Królestwa Polskiego lub snując rozważania nad udziałem kleru w życiu politycznym kraju, (zob. H. Koll ą t a j, Do Stanistawa Matachowskiego referendarza koronnego o przysztym seymie listów kilka. Cz. 1: O podźwignieniu sił krajowych, s. 37-80; cz. 2: O poprawie Rzeczypospolitej, s. 102-106, [b.m.] 1788). St. Staszic milczy o annatach. Okazją do zanotowania tych świadczeń mogło być dla niego np. omawianie obowiązków kleru wobec państwa (zob. St. S t as zic, Myśli polityczne dla Polski, Warszawa 1789, s. 116-134). 
jącą frakcją soboru zwalczali pierwszoroczne opłaty beneficjalne na rzecz Stolicy Apostolskiej. W roku zaś 1438 zebrani przedstawiciele świeccy oraz duchowni w Bourges uchwalili sankcję pragmatyczną, której dziesiąty punkt przejął odnośnie do annat opozycyjną uchwałę bazylejską ${ }^{42}$. W następnym roku parlament francuski dokonał recepcji sankcji pragmatycznej do swoich uchwał. Wprawdzie praktycznie duchowni dalej płacili annaty do Rzymu, lecz prawnie były one odtąd zabronione. Stolica Apostolska nie zaniedbywała okazji, ażeby doprowadzić do uchylenia sankcji pragmatycznej. Wysiłki te przyniosły nawet przejściowe sukcesy. Oto w 1461 r. król francuski Ludwik XI skasował postanowienia z Bourges celem pozyskania sobie papiestwa dla swej polityki we Włoszech. Pod mocnym jednak naciskiem parlamentu już w dwa lata później zostały zabronione wszelkie opłaty z beneficjów na rzecz Kurii Rzymskiej. Ponowne próby uzgodnienia stanowisk podjęto w 1472 r., w wyniku których papież Sykstus IV uzyskał znów na okres trzech lat zezwolenie króla na papieską prowizję beneficjów łącznie ze świadczeniami annatowymi ${ }^{43}$. Ostatecznie sytuację unormalizował dopiero konkordat zawarty pomiędzy Stolicą Apostolską a Francją w 1516 r., który włączono do uchwał V soboru lateraneńskiego (1512-1517). Konkordat uchylił sankcję pragmatyczną i między innymi sprawami zaaprobował opłaty z beneficjów, czyli przywrócił annaty ${ }^{44}$. Opozycja przeciw annatom istniała jednak nadal w społeczeństwie francuskim. Zniesienie ich usiłowały przeprowadzić Stany Generalne obradujące w Orleanie (1561 r.) oraz w Blois (1576 r.). Nie udało się też delegacji francuskiej wnieść tego zagadnienia pod obrady soboru trydenckiego. Ostatecznie więc usankcjonowane w konkordacie z 1516 r. annaty przetrwały tam aż do roku 1789, kiedy Stany Generalne powzięły decyzję całkowitego ich zniesienia. Decyzję tę zatwierdziło Zgromadzenie Narodowe i jakkolwiek Ludwik XVI uzależnił jej prawomocność od zgody papieża, sytuację tę przypieczętowała z kolei Rewolucja ${ }^{45}$.

$\mathrm{Na}$ terenie cesarstwa niemieckiego opozycja przeciw annatom nie miała tak dramatycznego przebiegu jak we Francji. Wprawdzie i tu nie brakło głosów krytycznych, lecz wyłaniające się spory załatwiano od razu w drodze obopólnej zgody. W ten sposób w 1448 r. został zawarty konkordat pomiędzy Stolicą Apostolską a cesarzem Fryderykiem III, zwany wiedeńskim, w którym powtarzając postanowienia uzgodnione w $1418 \mathrm{r}$. w Konstancji, jeszcze raz zagwa-

\footnotetext{
${ }^{42}$ Sankcja pragmatyczna uchyliła annaty we Francji po myśli soboru bazylejskiego, przyznając w razie konieczności papieżowi ich piątą część jako odszkodowanie (zob. HL 7/2 s. 1059).

${ }^{43}$ F. Mahon de Monaghan, jw., s. 287-290.

${ }^{44}$ HL 8 s. 492-493. Wprawdzie nie ma w konkordacie mowy wprost i wyraźnie o annatach, lecz mówi się o nich pośrednio. Mianowicie przy określeniu papieskiej prowizji beneficjów jest załączony postulat o podanie rocznych dochodów tego rodzaju stanowisk kościelnych. Zresztą parlament, ratyfikując konkordat, potwierdził ten moment, że w takiej taksacji beneficjów chodzi o annaty; - zob. R. A ubernas, R. Ricard, L'Eglise et la Renaissance, [w:] Histoire de L'Eglise, ed. A. Fliche, V. Martin, t. 15, Paris 1951, s. 171-174.

${ }^{45} \mathrm{~F}$. Mahon de Monaghan, jw., s. 305-319.
} 
rantowano papieską prowizję beneficjów oraz uznano świadczenia annato$w^{46}$. Na sejmie w 1479 r. Niemcy uskarżali się na annaty, a w roku 1510 przedłożyli nawet cesarzowi Maksymilianowi memoriał w tej sprawie, zawierający szereg postulatów. Ostatecznie jednak skończyło się na tym, że cesarz Karol V w 1522 r. zwrócił się do papieża Hadriana VI z bezskuteczną prośbą o pozostawienie annat w Niemczech na cele wojny $z$ Turkami i zarówno prawnie jak faktycznie pozostał nadal normą konkordat wiedeński z r. $1448^{47}$. Chwilowa groźba upadku annat przyszła tutaj dopiero przy końcu XVIII w. i to ze strony zgoła nie oczekiwanej, bo od samej hierarchii kościelnej. Wyrosła na ideach febronianizmu tzw. Punktacja Emska, zredagowana przez arcybiskupów niemieckich w 1785 r. pod patronatem cesarza, zawierała w 21. artykule stanowcze żądanie zniesienia annat ${ }^{48}$. Autorzy Punktacji nie znaleźli jednak szerszego poparcia w hierarchii niemieckiej i w ten sposób wysunięty przez nich program nacjonalizacji Kościoła wnet upadł. Zasadą pozostał stan prawny ze wspomnianego konkordatu wiedeńskiego.

W Polsce na odcinku poczynań praktycznych ośrodkami opozycji annatowej byli: duchowni, król, szlachta. Każdemu jednak z wymienionych czynników był właściwy inny stopień zaangażowania w tej akcji.

Obciążeni płatnością du ch ow n i nigdy nie występowali na tym polu w tak ostrej formie, jak np. kler francuski czy nawet niemiecki ${ }^{49}$. Można zanotować jedynie trzy przykłady ujawnionej przez duchownych chęci uwolnienia się od annat ${ }^{50}$. Trzeba zaś przy tym zaznaczyć, że nie były to otwarte żądania, lecz bardzo powściągliwe prośby oraz propozycje.

Pierwszym przykładem była wystosowana do Stolicy Apostolskiej w r. 1537 prośba o zwolnienie z annat przez biskupów Krakowa i Płocka ${ }^{51}$. Uczynili to pod naciskiem szlachty na sejmie krakowskim z roku 1536/7. Z okazji uchwalania kontrybucji wojennej podniosły się tam mianowicie głosy wrogie annatom, w wyniku czego na biskupach: Janie Latalskim (biskupie krakowskim, a w tym czasie już nominacie gnieźnieńskim) oraz Janie Chojeńskim (biskupie płockim i nominacie krakowskim) wymuszono zobowiązanie, że z okazji przeniesień na

${ }^{46}$ Quellen zur Geschichte des Papsttums und des römischen Katholizismus, hrsg. von D. C. Mirbt, Tübingen 1911, s. 178. Był to tzw. konkordat wiedeński.

${ }^{47}$ G. Philips, Kirchenrecht, t. 5, Regensburg 1854, s. 595; A. Puglie se, jw., s. 49.

48 "Herabsetzung der Annaten und Paliumsgelder in einer Nationalkirchenversammlung" (Quellen zur Geschichte des Papsttums..., s. 322); - por. L. Pas tor, Geschichte der Päpste seit dem Ausgang des Mittelalters, t. 16/3, Freiburg i. Br. 1933, s. 383

${ }^{49}$ Być może duchowieństwo polskie nie widziało sensu takich wystąpień, widząc w tym kierunku działania króla i szlachty. Faktem jest jednak, że zarówno kler wyższy, jak i niższy, nie wysunął nigdy przeciw Stolicy Apostolskiej jakiejś formalnej opozycji finansowej, zwłaszcza w odniesieniu do annat. Tendencje podobne w innych dziedzinach podkreśla także K. Górski w: Rzqdy wewnetrzne Kazimierza Jagiellonczyka w Koronie, „Kwartalnik Historyczny” 65:1959 s. 742-743.

${ }^{50}$ Pomijam tu, rzecz jasna, takie fakty, jak odosobnione prośby o rozłożenie płatności annat na raty czy sporadyczne popadnięcia w sankcje karne za nieterminowe wpłaty. Były to bowiem przejawy niedociągnięć dyscyplinarnych, nie zaś świadome poczynania zmierzające do podważenia praktyki annatowej.

51 VMPL 2 s. $522-523$ (n. 581). 
wymienione stolice nie wyślą annat do Rzymu, lecz je przekażą na obronę kraju. W tej sytuacji obydwaj biskupi odnieśli się do papieża, by uwzględnił te wyjątkowe okoliczności i darował skarbowi koronnemu ich taksy serwicjalne, czyli annatowe ${ }^{52}$.

Na tym samym tle doszło do drugiego ogólniejszego przykładu wystąpienia duchowieństwa polskiego przeciwko świadczeniom pierwszorocznym. Mianowicie na wymienionym sejmie krakowskim (1536-37) szlachta zobowiązała króla, by wysłal do Rzymu poselstwo z prośbą o wyjednanie u papieża annat na cele krajowe. Król początkowo zwlekał, lecz ostatecznie wyprawił do Stolicy Apostolskiej w tej sprawie Tomasza Sobockiego. W tym samym roku (1537), z rozkazu króla, odbył się pomimo śmierci prymasa, synod prowincjalny w Piotrkowie. Uchwalono na nim kontrybucję wojenną oraz $\mathrm{z}$ inspiracji króla zebrany tam kler wysłał do papieża list popierający poselstwo Tomasza Sobockiego, mającego wyjednać między innymi pozostawienie w kraju annat $^{53}$. W następstwie wymienionych starań papież $\mathrm{z}$ annat przysługująych mu od biskupów: gnieźnieńskiego, krakowskiego, płockiego i przemyskiego przeznaczył na wojnę z Tatarami 10000 złotych dukatów ${ }^{54}$.

Trzeci wreszcie przykład pochodzi z diecezji chełmskiej. Na synodzie diecezjalnym, odbytym w r. 1607 przez biskupa Jerzego Zamojskiego, poddano dyskusji przysłany przez prymasa Maciejowskiego program przyszłego synodu prowincjalnego ${ }^{55}$. Wśród proponowanych na obrady prowincjalne punktów znalazła się także sprawa annat. Była to mianowicie sugestia uchwały, ażeby za zgodą papieża przeznaczyć annaty na cele walki z innowiercami ${ }^{56}$. Uczestnicy synodu chełmskiego jednozgodnie poparli tę propozycję ${ }^{57}$. Jest jednak rzeczą ciekawą, że na synodzie prowincjalnym w Piotrkowie, który się istotnie odbył w październiku 1607 r., nie poruszono w ogóle tej kwestii. Przynajmniej nie ma o tym wzmianki w jego statutach ${ }^{58}$. Najprawdopodobniej uczestnicy synodu

52 W. Poci e ch a, Walka sejmowa o przywileje Kościoła w Polsce w latach 1520-1537, „Reformacja w Polsce" 2:1932 s. 183n.

53 Tamże; por. VMPL 2 s. 521 (n. 580).

${ }^{54}$ Analecta Romana, quae historiam Poloniae saec. XVI illustrant, ex archivis et bibliothecis excerpta, ed. J. Korzeniowski, Kraków 1894, s. 93 (n. 82); W. Wó j cik, Zagadnienie pomocy świeckiej w sprawach gospodarczych Kościoła w Polsce średniowiecznej, RTK 7:1960 z. 4 s. 78; VMPL 2 s. 555-556 (n. 625).

55 Jakub Sawicki zwraca uwagę, że synod chełmski z 22 września 1607 r. był pomyślany jako przygotowawczy do synodu prowincjalnego, zapowiedzianego na 8 października tegoż roku w piotrkowie. Zdaniem Sawickiego prymas, wraz z dekretem zwolującym synod, przysłal także jego przewidywany porządek dzienny, ażeby duchowieństwo mogło się z nim zapoznać, przedyskutować, przygotować wnioski; - zob. Concilia Poloniae, t. 9, Wrocław 1952, s. 20-21. W myśl tej uwagi podobne synody przygotowawcze powinny się odbyć i w innych diecezjach. Brak jednak na to wyraźnych potwierdzeń.

56 „Annatae eodem Sanctissimo non dissentiente, ut hic remaneant ad resistendum pravitati et vi hereticorum" (Concilia Poloniae, jw., t. 9 s. 131).

57 „Annatas hic retinendas, si fieri potest, omnes aprobaverunt” (tamże, s. 132).

58 Concilium Provinciale quod [...] Bernardus Maciejowski [...] habuit Petricoviae a. D. 1607, [w:] Constitutiones synodorum metropolitanae ecclesiae Gnesnensis provincialium, ed. J. W ęż y k, Cracoviae 1761, dodatek (bez paginacji). 
uznali za stosowne nie zwracać się w tej sprawie do Rzymu przez wzgląd na uchwałę sejmową z maja tego samego roku. Uchwała nakazywała biskupom przekazywanie do skarbu państwa takiej samej sumy, jaką tytułem annat płacą do Rzymu ${ }^{59}$. Wyszłoby więc wobec Stolicy Apostolskiej, że duchowieństwo polskie współdziała z czynnikami świeckimi w uszczuplaniu praw papieskich.

Wystąpienia przeciwannatowe k róló w pols k i ch były również nacechowane wielkim umiarem ${ }^{60}$. Wyrażały się one zawsze w pełnych taktu prośbach. Tak więc już Kazimierz Jagiellończyk w r. 1468, polecając na biskupstwo kamienieckie kanonika lwowskiego Piotra Gołąbka, prosił papieża Pawła II o względy przy egzekwowaniu opłat annatowych $\mathrm{z}$ powodu zniszczeń wojennych w Kamieńcu ${ }^{61}$. W r. 1481 ten sam monarcha na wiadomość o podwyżce taksy annatowej dla biskupstwa płockiego, zwrócił się do pap. Sykstusa IV $\mathrm{z}$ oświadczeniem, że sprzeciwia się ewentualnej podwyżce annat dla archidiecezji gnieźnieńskiej62. W podobny sposób odnosił się do papieża w materii annat król Zygmunt Stary (1506-1548). Zwracając się w latach 1527, 1531, 1533 do Rzymu o zatwierdzenie na stolicach biskupich kilku kandydatów (Andrzeja Krzyckiego, Jana Karnkowskiego, Macieja Drzewickiego, Jana Chojeńskiego, Wacława Wierzbickiego), za każdym razem dołączał prośbę o nieobciążanie nadmierne annatami jego nominatów ${ }^{63}$. W 1527r. tenże władca odniósł się do pap. Klemensa VII z formalnym wnioskiem o pozostawienie annat w Polsce na koszty wojen z niewiernymi. Była to również prośba wyrażona w łagodnej formie („concedere dignetur”) ${ }^{64}$. Takie same wystąpienia wypada dostrzec ze strony króla Stefana Batorego (1576-1587). Nuncjusz papieski w Polsce Albert Bolognetti pisał w 1583 r. do Kurii Rzymskiej, że król polski sprzeciwial się na ostatnich sejmach wysuwanym żądaniom zniesienia annat, broniąc na tym odcinku praw Stolicy Apostolskiej. Obstawał on (tj. król Stefan Batory) jedynie przy tym, ażeby odnośnie do tych świadczeń mieć wzgląd na zniszczone wojnami biskupstwo inflanckie ze stolicą w Wenden ${ }^{65}$. Oględne w treści i w tonie wystąpienia królów przeciw annatom papieskim nie wywarły żadnego wpływu na losy tej praktyki w Polsce. Realizowano ją więc bez zmian.

W całej pełni opozycyjnym czynnikiem w materii annat była szlachta pols k a. Pod jej naciskami pozostawali sami królowie. Szlachta wyrażała swo-

${ }^{59}$ Volumina Legum. Przedruk zbioru praw staraniem XX Pijarów w Warszawie od roku 1732 do roku 1782 wydanego, t. 2, Petersburg 1859, s. 436 (n. 1602).

${ }^{60}$ Królowie polscy pozostawali pod silnym naciskiem szlachty, jeśli chodzi o ich wystąpienia przeciwannatowe. Podkreślają to mocno w swoich sprawozdaniach nuncjusze papiescy w Polsce, np. Lippomano w r. 1556 czy Ruggieri w r. 1568; - zob. E. R y k a cze w s ki, Relacje nuncjuszów apostolskich i innych osób o Polsce od roku 1548 do 1690, t. 1, Berlin-Poznań 1864, s. 39, 313.

${ }^{61}$ Codex epistolaris saeculi XV, t. 3, Cracoviae 1894, s. 137.

${ }^{62}$ Tamże, t. 1 , Cracoviae 1876, s. 360.

$63, \ldots[. .$.$] ne in annata et expeditionibus suis illi ipsi nominati mei plus aequo graventur" (Acta$ Tomiciana, ed. S. Górs k i, W. Pociech a, t. 9, Posnaniae 1901, s. 103 n. 97; t. 13, Posnaniae 1915, s. 181 n. 184).

64 Tamże, t. 9 s. $99-100$ (n.91).

65 MPV 6 s. 429 (n. 247). 
je stanowisko w tej sprawie na sejmach. Dlatego należy się przyglądnąć z kolei przeciwannatowej działalności polskich sejmów z tamtych czasów. Działalność tę wszczął wspomniany już wyżej sejm krakowski z 1536/7 roku. Oprócz omawiania innych zagadnień beneficjalnych, uczestnicy sejmu domagali się przeznaczenia annat papieskich na obronę kraju. Gorliwym rzecznikiem praw Stolicy Apostolskiej był tam biskup płocki Jan Chojeński. Król jednak uległ naleganiom stanu szlacheckiego i w 1537 r. wysłał do papieża Pawła III posła (Tomasza Sobockiego), mającego wyjednać darowiznę annat, o czym była mowa powyżej. Polska szlachta nie zadowoliła się jednak połowicznym załatwieniem sprawy. Zagadnienie annat wniesiono ponownie pod obrady sejmu piotrkowskiego z 1544 r. ${ }^{66}$ Podjęto tam formalną uchwałę zobowiązującą króla, ażeby wysłał do Rzymu poselstwo celem wyjednania u papieża dla skarbu państwa annat płaconych wbrew dekretowi bezylejskiemu ${ }^{67}$. Zygmunt II August wysłał rzeczywiście swego posła do papieża, lecz ten nie uzyskał darowizny annat. W zamian jednak za to Paweł III po raz drugi przyznał Polsce jednoroczną subwencję pieniężną w kwocie 100000 skudów, tj. około 12000 złotych dukatów ${ }^{68}$.

Zagadnienie annat odżyło na nowo w czasie zjazdu w Piotrkowie w r. 1567. Spośród wielu wydanych tam konstytucji, jedna dotyczyła właśnie opłat pierwszorocznych. Wedle niej miały one za pozwoleniem króla pozostać w kraju na cele obrony ${ }^{69}$. Niejasne jest sformułowanie tej konstytucji. $Z$ jednej strony miało to być niby zarządzenie wiążące, $\mathrm{z}$ drugiej zaś zostało ujęte $\mathrm{w}$ formę dowolnej wskazówki. Jest to odzwierciedlenie faktycznej sytuacji współczesnej. Król mianowicie, nie mając upoważnienia w tym względzie od Stolicy Swiętej, nie chciał się narażać na otwarty konflikt z papieżem. Z drugiej zaś strony musiał ustąpić naciskowi szlachty. Wybrał więc drogę pośrednią, to znaczy ustąpił wobec żądań posłów i senatorów, gdyż zgodził się, by annaty przeznaczyć na cele krajowe. Wobec Stolicy Apostolskiej zachował się jednak nienagannie, albowiem powzięta uchwała nie przybrała charakteru formalnego nakazu, lecz normy zezwalającej: „pozwalamy, aby annaty w Koronie zostały na obronę Rzeczypospolitej”. Tenor powyższej konstytucji zmienił się całkowicie w dwa lata później. Na sejmie lubelskim w 1569 r., gdzie porządkowano sprawy unijne Polski z Litwą, poruszono również zagadnienie annat papieskich. Powołując się na konstytucję piotrkowską sprzed dwu lat postanowiono, że annaty

${ }^{66}$ W. Sk rze tu ski, Prawo polityczne narodu polskiego, t. 2, Warszawa 1787, s. 23.

${ }^{67}$ Volumina Legum, jw., t. 1, Petersburg 1859, s. 286. To oficjalne odwołanie się na sejmie do uchwał soboru bazylejskiego jest dowodem, że część szlachty polskiej jeszcze w XVI w. ulegała koncyliaryzmowi.

${ }^{68}$ B. De m bińs ki, Sprawozdanie z poszukiwań $w$ archiwach i bibliotekach rzymskich szczególniej w archiwum watykańskim, Kraków 1888, s. 90—93.

69 „Pozwalamy, aby annaty w Koronie zostały na obronę Rzeczypospolitej” (Volumina Legu$n a$, jw., t. 2 s. 69). 
mają być przekazywane do skarbu państwa pod karą podwójnej ich kwoty ${ }^{70}$. W ten sposób po raz pierwszy w ustawodawczej działalności sejmów uchylono papieskie annaty. W dosłownym brzmieniu powtórzył tę konstytucję sejm w Andrzejowie w r. $1576^{71}$.

Ale biskupi w dalszym ciągu słali do Rzymu swoje taksy serwicjalne. Dlatego poświęcił im znów swoją uwagę sejm warszawski z 1607 r. Ujął on w jedną całość dotychczasowe zarządzenia państwowe o annatach oraz dodał do nich nowe elementy. Konstytucja annatowa sejmu warszawskiego składa się z kilku części. Nawiązując po pierwsze do poprzednich, nakazuje ona biskupom przekazywanie do skarbu państwa na obronę Rzeczypospolitej równej annatom papieskim kwoty w terminie jednego roku od otrzymania sakry ${ }^{72}$. Po drugie ustanawia nieco inne sankcje na wypadek nieprzestrzegania ustawy. Kara wyrażała się, jak poprzednio, w podwójnej kwocie annatowej, którą należało egzekwować z dóbr własnych zainteresowanego biskupa, wobec zaś braku takowych, $\mathrm{z}$ dochodów beneficjalnych. Po trzecie, i to jest całkowitą nowością, konstytucja określiła procedurę przymusowego ściągania należności ${ }^{73}$. Na ich egzekutora, z powiadomienia urzędników skarbowych, powołano mianowicie instygatora królewskiego, który własnymi dobrami miał odpowiadać przed sejmem za swe czynności w tym zakresie ${ }^{74}$. Po czwarte konstytucja określała swoją moc obowiązującą w odniesieniu do kolidujących z nią praw Stolicy Apostolskiej. Zakładając uzgodnienie tej sprawy z papieżem, konstytucja zobowiązywała od razu, bez względu na wynik starań w Rzymie, przy nadrzędnym jednak założeniu, że nie zamierza ona naruszać uprawnień Stolicy Świętej $^{75}$. W porównaniu zatem z poprzednimi, nowością konstytucji sejmowej

70 „Annaty, które Seymową konstytucyą są pozwolone na obronę potoczną, tamże mają być oddawane od possessora od konstytucyi dwuletniey Piotrkowskiey pod winą duplicis annatae" (tamże, s. 95).

71 „Annaty Ich Mość Księża Biskupi, wedle konstytucyi anni 1567 et anni 1569 powinni oddawać tamże w Warszawie do skarbu koronnego sub paenis ibidem expressis" (tamże, s. 156); - por. A. Pa wińs ki, Skarbowość w Polsce i jej dzieje za Stafana Batorego, Warszawa 1881, s. 142.

72 „Do effektu przywodząc Statut króla Zygmunta Dziada y Zygmunta Augusta Wuia Naszego y Stefana, Przodków Naszych, Constytucye o Annatach uczynione: postanawiamy, aby każdy z księży Arcybiskup y Biskup, którzy od nas beneficja otrzymywać będą takową sumę, jaką do Rzymu nomine Annatae dawaią dać był powinien, koronny do skarbu Koronnego, litewski do Skarbu Wielkiego Xiąstwa Litewskiego w rok po expedycyey Sycry, na obronę Rzeczypospolitej" (Constytucye statuty przywileie Koronne y W. X. Lit., wyd. S. K ȯ̇u ch ows k i, Mokrsk 1732, s. 9). Por. Volumina Legum, jw., t. 2 s. 436.

73 "Sub poena duplicis summae de bonis mobilibus et immobilibus propriis; in defectu vero de proventibus et redditibus repetenda" (Constytucye..., s. 9).

74 „O co Instygator Nasz ex delatione officialium Thesauri nostri, czynić będzie powinien sine intermissione, pod zapłaceniem de suo teyże sumy, z Instygacyey Posłów Ziemskich na seymie; a podskarbi Koronny do Rawy to wnosić, y rachunek czynić z tego, a Litewski na obronę Rzeczypospolitej także obracać ma" (Constytucye..., s. 9). Instygator królewski byl to urzędnik spotykany w dawnej Polsce od roku 1581, którego funkcja odpowiadała obowiązkom dzisiejszego prokuratora. Miał on za zadanie obronę interesów króla; - zob. Encyklopedia staropolska, wyd. Z. Gloge r, t. 2, Warszawa 1958, s. 274-275.

75 "Ażeby to już w wątpliwość przywodzone nie było, Oyca Ś. w tey mierze pozwolenia dosiężemy y choćby też prze jakie przyczyny effektu to nie wzięlo, teraźnieysze postanowienie vim et robur suum mieć ma, absque tamen derogatione Iuris Apostolici” (Constytucye..., s. 9-10). 
z r. 1607 było nałożenie na biskupów świadczeń na rzecz skarbu państwa, odpowiadających annatom papieskim, te zaś pozostawiła nietknięte. Wskazywała wyraźnie na to jej końcowa klauzula: ,absque tamen derogatione iuris apostolici".

Tak więc z ognia walki prowadzonej przez szlachtę na sejmach praktyka annat papieskich wyszła sama w sobie zwycięsko. Ofiarę ponieśli biskupi polscy, którzy zostali objęci obowiązkiem drugich świadczeń na skarb państwa, analogicznych do annat papieskich. Należy jednak zwrócić uwagę, że powyższy obowiązek w myśl konstytucji spoczywał wyłącznie na arcybiskupach i biskupach, nie obejmował natomiast opatów i tych beneficjatów niższych, na których ciążyły annaty z prawa kościelnego. Gdyby wziąć pod uwagę postanowienie konstytucji sejmowej z 1607 r., że należy dokonywać wpłat „,w rok po ekspedycyi sakry", to obowiązywała ona wyłącznie tych kandydatów na stolice biskupie, którzy obejmowali diecezje po raz pierwszy, nie mając jeszcze sakry.

Wykonywanie przez biskupów uchwał sejmowych, polecających przekazywanie państwu annat, nie było faktycznie zbyt regularne. Tzw. ,rejestry kwarciane" z okresu króla Stefana Batorego podają, że świadczenia te nie dochodziły do skarbu rawskiego. W każdej niemal księdze, zawierającej roczne obroty, spotykamy tam w dziale długów uwagę, że wyżsi duchowni nie wywiązali się z obowiązku tych wpłat. Wyjątkiem pod tym względem byli dwaj biskupi krakowscy: Franciszek Krasiński (1572-1577) i Piotr Myszkowski (1577-1591), oraz biskup włocławski Stanisław Karnkowski (1567-1581), którzy uiścili te świadczenia ${ }^{76}$. Po zaostrzeniu sankcji karnych w konstytucji sejmowej z r. 1607 faktyczna płatność tych świadczeń niewątpliwie się podniosła. Zapewne jednak nie była zadowalająca $\mathrm{z}$ punktu widzenia skarbu państwa, ponieważ w r. 1775 na nadzwyczajnym sejmie warszawskim wprowadzono tzw. ,papier stemplowy", tzn. opłaty skarbowe z racji załatwiania czynności urzędowych. Przy tej okazji obłożono wysoką opłatą stemplową dokumenty prowizyjne urzędów biskupich ${ }^{77}$. W ten sposób od tego czasu biskupi wraz z annatami ponosili na rzecz skarbu państwa jeszcze dodatkowe ciężary płatnicze. Było to jak gdyby wprowadzenie państwowych taks annatowych ${ }^{78}$. Od tego czasu zagadnieniem annat nie zainteresowal się żaden z sejmów; nie wysunięto też w tej sprawie ze strony czynników państwowych żadnych pretensji ${ }^{79}$.

\footnotetext{
${ }^{76}$ Księgi skarbowe, zwane księgami kwarty, z r. 1578 notują: „Annatae ab episcopis iuxta constitutiones sunt omnes retentae, nullus enim eorum eandem thesauro r. p. intulit, preter olim Krasiński episcopum cracoviensem et modernum episcopum cuiaviensem". Podobne notatki zawierają księgi kwarciane z 1580 i 1581 r. Odnośnie do bpa Myszkowskiego jest osobne świadectwo króla z r. 1578, że „annatam ex episcopatu Cracoviensi intulit, quam nos in usum belli Gedanensis conversam esse hisce litteris nostris testamur" (A. Pawiński, jw., s. 143 przypis 1).

77 Volumina Legum, t. 8, Petersburg 1860, s. 94.

78 W. Skrzetuski, jw., t. 2, s. 24.

79 Wymownym tego przykładem jest zaprojektowany przez A. Zamojskiego w latach 17761778 Kodeks ustaw. Projekt ten obejmował, wbrew pierwotnym intencjom twórców, prawie całokształt zagadnień wewnątrzpaństwowych. Nie uwzględnial on w ogóle annat; - zob. M. Ta r-
} 
Warto podkreślić, że ten korzystny dla annat papieskich w Polsce bilans kontrowersji wyróżnia się szczególnie w porównaniu na przykład ze stosunkami francuskimi. O ile bowiem we Francji u podstaw państwowej opozycji annatowej leżały zasady gallikanizmu i ekonomicznego merkantylizmu, o tyle u nas wybijały się na czoło rzeczywiste potrzeby finansowe na obronę kraju. Ostatecznie wybrano u nas kompromis, którego mocą i prawa Stolicy Świętej do annat nie zostały podważone, i budżetowe potrzeby skarbu państwa zostały w stopniu oczekiwanym zaspokojone. Na tym polegała specyfika tej problematyki w Polsce. Powyższy, specyficzny profil kontrowersji wokół annat papieskich w Polsce był owocem ogólnego trendu w naszej kulturze, u podstaw którego leżała w gruncie rzeczy wierność wobec Stolicy Apostolskiej oraz Kościoła. Konkretnym tego przejawem w omawianej dziedzinie było wystąpienie czynników w obronie annat, które we wspomnianej atmosferze mogły dojść do głosu oraz wywierały faktyczny wpływ na obrót sprawy.

II

\section{OBRONA ANNAT PAPIESKICH}

Po raz pierwszy w dziejach dokonał obrony zagrożonej w swoim bycie instytucji annat sobór w Konstancji (1414-1418). Była to obrona w skali ogólnokościelnej i zarazem o charakterze ogólnoustawodawczym, prawotwórczym. Po soborze konstancjańskim już nigdy w takim zakresie oraz w takim stopniu nie podjęto apologii tej instytucji. Zagadnienie to kształtowało się od tego czasu partykularnie. Partykularny bowiem charakter miała opozycja kierowana przeciwko annatom. Nawet na reformistycznym soborze bazylejskim (1431-1437) wrogie tej instytucji tendencje zachowały cechy partykularyzmu. Taki rodzaj opozycji domagał się przeto podobnej przeciwakcji. Stąd też Stolica Apostolska na sposób uwarunkowany konkretnymi okolicznościami wkraczała tu sama jako obrończyni własnych praw. W XV w. przykłady tego rodzaju interwencji były stosunkowo rzadkie i poznaliśmy je wyżej w ramach uwag poświęconych omówieniu czynników zwalczających annaty. W XVI stuleciu przybrała na sile walka $\mathrm{z}$ annatami. Pociągnęło to za sobą stosowne zabiegi zmierzające do ich obrony, jednakże w taktyce tych zabiegów śledzimy poważne zmiany. W następstwie powstania w poszczególnych krajach papieskich przedstawicielstw dyplomatycznych, zadanie obrony praw Kościoła zarówno na płaszczyźnie religijnej jak politycznej podjęli nuncjusze Stolicy Apostolskiej. Oni to więc stali się także obrońcami annat. Nie ulega wątpliwości, że

n a w s ki, Kodeks Zamoyskiego na tle stosunków kościelno-państwowych za czasów Stanistawa Augusta, Lwów 1916, s. 33, 65. Gdyby więc annaty zajmowały wówczas publiczną opinię, to musiałyby być poruszone na wskazanych miejscach Kodeksu. 
przede wszystkim ich poczynaniom należy przypisać duże sukcesy w tej dziedzinie. Rolę nuncjuszy omówimy tu zatem na pierwszym miejscu. Obok nuncjuszy, którzy działali niejako z urzędu i w formie bezpośredniej, do obrony annat przyczynili się znacznie także ludzie pióra, uczeni. Ich wystąpienia nie były tak doraźne i bezpośrednie, lecz pośrednio tworzyły atmosferę sprzyjającą annatom, osłabiały nastroje przeciwannatowe, co na dłuższą metę miało doniosłe znaczenie. Poświęcimy im zatem uwagę w drugim punkcie niniejszego rozdziału.

\section{DZIAŁALNOŚĆ NUNCJUSZY PAPIESKICH}

Interwencje w obronie annat podejmowane przez nuncjuszów czy legatów papieskich zdarzały się często w krajach zachodnich. Np. pap. Pius IV (15591565) wysłał w roku 1561 poselstwo do króla Karola IX w obronie zagrożonych annat we Francji. ${ }^{80}$ Podobnie w Niemczech, wymierzoną między innymi przeciwko annatom Punktację Emską z 1785 r. podważali skutecznie wysłani tam specjalnie nuncjusze Stolicy Apostolskiej ${ }^{81}$.

Analogicznie miała się rzecz u nas. Nuncjusze papiescy w Polsce zwracali baczną uwagę na praktykę annatową, informując pilnie Kurię Rzymską w tym względzie oraz broniąc tych świadczeń na miejscu. Stolica Apostolska zaś trzymała się świadomie metody, by pouczać w instrukcjach, jakie stanowisko winni zajmować jej przedstawiciele. O nastrojach przeciwannatowych w Polsce informowali Stolicę Apostolską w swoich obszerniejszych sprawozdaniach tacy nuncjusze, jak: Camerino w 1563 r., Lippomano w 1566 r., Ruggieri w 1568 r., Calighari w 1581 r., Possevin w 1583 r., Bolognetti w 1583 r. ${ }^{82}$ Spośród wymienionych nuncjuszów w sposób gruntowniejszy najpierw Ruggieri oraz Calighari donosili w swoich sprawozdaniach o podejmowanych przez siebie akcjach w obronie zagrożonych annat w Polsce.

J. Ruggieri w r. 1568 pisał, że dzięki zabiegom, jakie poczynił u króla polskiego, nie weszła w życie uchwała sejmu piotrkowskiego, odmawiająca papieżowi świadczeń annatowych, przeznaczająca je na obronę kraju ${ }^{83}$. Nuncjusz miał na myśli zjazd w Piotrkowie z 1567 r., na którym istotnie wydano konstytucję przeciwannatową ${ }^{84}$. Drugim osiągnięciem, jakie sobie J. Ruggieri przy-

${ }^{80}$ Posłem papieskim w tej sprawie byl kardynal Ferrari Hipolit; - zob. F. Mohon de Monagh an, jw., s. 306-307.

${ }_{81}^{81}$ L. F. Pastor, jw., t. 16/3 s. 385.

${ }^{82}$ E. Rykaczews ki, jw., t. 1 s. $39,110,213$; MPV 4 s. $562,567,569 ;$ t. 6 s. $417,429$.

83 „Lubo król na ostatnim sejmie piotrkowskim [...] zezwolił na wykonanie prawa zapadłego jeszcze pod panowaniem jego ojca, którem postanowiono nie płacić Rzymowi annatów od beneficjów duchownych, ale je w kraju zatrzymać i obrócić na potrzeby wojny i inne publiczne użytki, mimo to jednak z niemałą trudnością wyjednalem, że prawo to w wykonanie nie weszło" (E. Rykaczewski, s. 213).

${ }^{84}$ Zob. wyżej przypis 71 . 
pisał w dziedzinie działalności na rzecz obrony annat, to zezwolenie króla, aby mianowany świeżo biskup włocławski przekazał Kurii Rzymskiej swoje dochody pierwszoroczne. Chodziło tu o Stanisława Karnkowskiego, który otrzymał diecezję włocławską w $1567 \mathrm{r}$. Uchwała bowiem piotrkowska zabraniała w ogóle biskupom przekazywania annat do Rzymu. Tym się też tłumaczy potrzeba interwencji nuncjusza ${ }^{85}$. Należy zauważyć, że ta interwencja Ruggieriego była osiągnięciem wielkiej miary. Stworzyła bowiem precedens stosowania praktyki podwójnych annat, jednych do Kurii Rzymskiej, drugich do skarbu państwa. Praktyka ta ostatecznie zwyciężyła i została usankcjonowana ustawą sejmu warszawskiego z 1607 r., o czym była mowa powyżej.

$\mathrm{Na}$ bardzo szeroką skalę podejmował obronę annat w Polsce inny nuncjusz papieski - J. J. Calighari. Obszerne sprawozdanie z tej działalności daje on w swoim piśmie do Stolicy Apostolskiej z 26 lutego z 1581 r. ${ }^{86}$ Wynika z niego, że nuncjusz z okazji jakiegoś sejmu, wobec króla i licznie zebranej szlachty, wygłosił długie przemówienie poświęcone obronie annat. Ponieważ pismo nuncjusza jest datowane w lutym, przeto nie może tu wchodzić w grę sejm warszawski z 6 marca 1581 r. Chodzi tu zapewne o sejm odbyty również w Warszawie dnia 5 stycznia $1580 \mathrm{r}$. W związku z projektowanymi tam nowymi podatkami wojennymi, najprawdopodobniej przygotowano jakiś zamach na papieskie annaty, wobec czego nuncjusz czuł się zobowiązany przeprowadzić ich gruntowną obronę. On sam dał temu wyraz, kiedy podkreślił w sprawozdaniu do Stolicy Apostolskiej, że starał się przekonać króla, biskupów, posłów i senatorów, przy wkładzie nadzwyczajnego wysiłku i doborze argumentów ${ }^{87}$. Podkreślił równocześnie, że jego przemówienie ogromnie wzruszyło króla oraz zebranych tak, że w jego przekonaniu wysiłek ten „nie pójdzie na marne”. Warto zapoznać się najogólniej z treścią tego przemówienia nuncjusza, ażeby mieć świadomość argumentów, jakimi współcześnie przeprowadzano apologię annat ze strony Kościoła.

Posługując się najpierw racjami prawno-historycznymi, przedstawiciel papieża uzasadniał samą genezę annat. Świadczenia te, mówił, są tak dawne jak dawnym jest zakładanie przez Stolicę Apostolską biskupstw oraz klasztorów. Wprowadzono je pierwotnie dla podkreślenia zwierzchnictwa Kościoła Rzymskiego nad wszystkimi innymi, później dołączył się także motyw utrzymania papieża oraz kardynałów, roztaczających pieczę nad całym chrześcijaństwem. Następnie J.J. Calighari przytoczył argumenty finansowe. Wykazywał mianowicie, że globalnie wzięte sumy pieniężne ze świadczeń annatowych w Polsce, nie równoważą bynajmniej wydatków i kosztów ponoszonych przez papieża na rzecz tego królestwa. Te wydatki i koszty są zdecydowanie większe. Nuncjusz

${ }^{85}$ E. Rykaczewski, jw., s. 213; A. Pawiński, jw., s. 143.

${ }^{86}$ MPV 4 s. 567 nn. (n. 316).

$87,[. .$.$] io ho usato diligenza estraordinaria et informato li vescovi, nuntii et senatori amici, et$ di piu S. M-ta, ce molte ragioni” (MPV 4 s. 567). 
wyliczył przy tym korzystne dla kraju pozycje, które wówczas finansowała Stolica Apostolska. Były nimi: utrzymywanie własnym kosztem stałego nuncjusza w Polsce, seminariów duchownych dla Polaków: w Braniewie, Ołomuńcu, Collegium Germanicum w Rzymie, do którego mieli na równi wstęp i duchowni polscy, świadczenie polskiej szlachcie rozległych przywilejów, wreszcie wspomaganie biednych oraz przygodnych pielgrzymów polskich w Rzymie. $\mathrm{Na}$ końcu reprezentant papieski wyliczył motywy religijno-polityczne. Dowodził mianowicie, że działalność zmierzająca do uchylenia annat pochodzi głównie ze źródeł heretyckich. Innowiercom bowiem zależy na doprowadzeniu po tej linii do całkowitego poróżnienia z papieżem a nawet do schizmy. Ucierpi zaś na tym tylko kraj, ponieważ zarówno w oczach papieża jak całego chrześcijaństwa upadnie autorytet króla oraz społeczeństwa polskiego.

J.J. Calighariemu należy przypisać jeszcze jedno wystąpienie w obronie annat. Miało ono, w przeciwieństwie do poprzedniego, charakter pośrednich zabiegów. Otóż w tym samym sprawozdaniu do Kurii Rzymskiej z 26 lutego 1581 r. nuncjusz donosił, że wśród wielu artykułów zwróconych przeciw Kościołowi, jakie heretycy przedłożyli królowi przez posłów ziemskich, mieścił się także artykuł zwalczający annaty. W następnym sprawozdaniu, z 10 marca tego samego roku, Calighari pisał, że ów heretycki artykuł przeciwannatowy odżył znów na zgromadzeniu posłów ziemskich, lecz za annatami wygłosił wtedy wspaniałe przemówienie Stanisław $\mathrm{Czarnkowski,} \mathrm{w} \mathrm{wyniku} \mathrm{czego} \mathrm{wy-}$ mieniony projekt całkowicie upadł. Wystąpienie St. Czarnkowskiego najprawdopodobniej nie było przypadkowe, lecz został on wysunięty przez koła kościelne, reprezentowane przez nuncjusza. W tym to znaczeniu należy tu rozumieć pośrednią rolę obrończą samego Calighariego.

Nie ulega wątpliwości, że oprócz wymienionych, inni nuncjusze także podejmowali obronę świadczeń annatowych, chociaż brak jest na to potwierdzenia w dostępnym materiale źródłowym ${ }^{88}$. Przytoczone przykłady wystarczają jednak całkowicie do ogólniejszego stwierdzenia, że działalność na tym polu przedstawicieli Stolicy Apostolskiej była bardzo czynna. Tej działalności należy przypisać ogromną część sukcesu, że praktyka annatowa przezwyciężyła w Polsce kierowane przeciw niej ataki.

${ }^{88}$ Tak np. na rzecz annat interweniował prawdopodobnie nuncjusz Ruini. Wskazuje na to instrukcja, jaką otrzymał w Rzymie (1612). Polecono mu w niej zapobiec spodziewanej w Rzymie petycji z Polski o pozostawienie annat w kraju. Czytamy w instrukcji: ,[... ponieważ Stolica Apostolska poniosłaby znaczną stratę, gdyby annaty przestały jej być płacone [...] przeto papież żadnym sposobem zezwolić na to nie może i w tem nieodmiennem pozostanie postanowieniu, choćby nawet żądanie takowe ponowione być miało, jak słychać, że ponowione będzie przez posła mającego tu przybyć z oświadczeniem posłuszeństwa. Gdyby chciano traktować o tem z J. W. Panem, daje mu się ta krótka informacja, abyć wiedzial, co komu odpowiedzieć i dal poznać komu wypadnie, jak to żądanie jest niesłuszne i nieprzyzwoite" (E. R y k a czew s ki, jw., t. 2 s. 113-114). 


\section{DZIAŁALNOŚ́ PISARZY}

W ślad za wyrosłą na gruncie koncyliaryzmu i gallikanizmu literaturą zwalczającą annaty, powstawaly także pisma przeciwne, tj. biorące w obronę te świadczenia. Pierwsze z nich nie dochowały się do naszych czasów. Znamy je tylko z pośrednich przekazów późniejszych. W skali ogólnej pierwszym obrońcą annat był Massa Antonius G all e si u s, który napisał rozprawę o annatach: De annatis sermo ${ }^{89}$. Bardzo gruntownie i systematycznie przeprowadza wykład nauki annatowej autor obszernego dzieła kanonistycznego - P. Fagn a nus. Rozprawia się on ze wszystkimi przeciwnikami annat, począwszy od Jana Gersona oraz daje ich wszechstronną obronę. W części apologetycznej zestawia autor cały szereg argumentów, w których wykazuje zasadność i godziwość tej praktyki. Dowodzi więc, że praktyka ta jest pozbawiona wszelkich cech symonii. Nie jest to bowiem pobieranie opłat za nadawanie stanowisk, lecz z okazji nadawania beneficjów, w drodze rezerwowanych sobie dochodów pierwszorocznych, do czego papieże mają pełne prawo na mocy władzy prymatu. Same dochody nie są ze swej natury czymś duchowym, lecz materialnym, doczesnym i stąd pobieranie ich dodatkowo nie ma nic wspólnego z symonią, która polega na kupczeniu rzeczami duchowymi ${ }^{90}$. W dalszym toku obrony annat autor wykazuje, że świadczenia te przysługują papieżowi tak z prawa Bożego naturalnego, pozytywnego jak też z prawa kościelnego, jako słuszne środki utrzymania. W doborze argumentacji daje się tu zauważyć, że autor chce z jednej strony bronić annaty przed zwolennikami koncyliaryzmu, którzy w tych świadczeniach dopatrywali się do przesady symonii, z drugiej zaś przed szermierzami gallikanizmu, którzy ograniczając kompetencję papieża w Kościołach partykularnych, odmawiali mu prawa do tych świadczeń. Dzięki wszechstronnemu opracowaniu instytucji annat, a także dzięki ukazaniu ich w świetle pozytywnych motywów prawnych, P. Fagnanus jest niewątpliwie i w tej dziedzinie klasycznym autorem. $\mathrm{Z}$ jednej strony podsumowuje on dotychczasowe poglądy na ten temat, $\mathrm{z}$ drugiej zaś staje się ich obszernym źródłem na przyszłość.

Pisemną obronę annat papieskich podejmowano także w Polsce, co nas tutaj głównie obchodzi. Wystąpienia polskich ludzi pióra na tym odcinku, jakkolwiek nie są pozbawione podkładu naukowego, mają jednak przeważnie charakter publicystyczny. Publikacje w tym zakresie przypadają przeważnie na koniec XVI oraz pierwszą połowę XVII w. Zasługują zaś na osobne omówienie, ponieważ do teorii annat wnoszą elementy nowe, oryginalne, właściwe stosunkom polskim, na które też głównie zwrócimy tutaj uwagę.

${ }^{89}$ Poza bibliograficzną informacją o tym traktacie, nie udało mi się dotrzeć do jego tekstu.

${ }^{90} \mathrm{P}$. F a g a n u s, Ius canonicum sive commentaria absolutissima in quinque libros decretales, t. 3, Coloniae 1676, pars 2, 1. 1 s. 559, n. 104. 
Pierwszym, który w tym duchu skreślił kilka uwag na temat annat, był Mikołaj Dobrocieski, doktor obojga praw, kanonik krakowski i sandomierski, zmarły w $1608 \mathrm{r}$. Napisał on dziełko pt. Informacya o niektórych artykutach między duchownym a świeckim stanem tych czasów ludziom do wiadomości potrzebna (Kraków 1632). Rozprawa ta dotyczy głównie dziesięcin, lecz kilka stronic dotyczy w niej także annat. Czasu napisania nie da się z dokładnością ustalić. Na podstawie kryteriów wewnętrznych można powiedzieć tyle, że dziełko powstało przed r. 1607, ponieważ autorowi jest nieznana pochodząca $\mathrm{z}$ tego okresu annatowa konstytucja sejmowa. Czy jednak zostało napisane bezpośrednio przed tym rokiem, czy też jeszcze w XVI w., tego nie można stwierdzić. Należy je więc odnieść średnio na przełom XVI i XVII w. Do naszych czasów dochowało się w przedrukach z r. 1620 i 1632 . Zawarte w Informacyi uwagi na temat annat są bardzo skąpe co prawda, lecz zasługują na podkreślenie dlatego, że są pierwszymi tego rodzaju u nas oraz, że główne myśli w niej wyrażone powtarzają się w późniejszych apologetycznych pismach annatowych. Rozumowanie Dobrocieskiego można by ująć w następujący schemat: papież ma prawo do pobierania annat, oparte na starotestamentalnych pierwocinach oraz dziesięcinach; z prawa tego zwierzchnik Kościoła faktycznie korzystał w ciągu dziejów, a zatem wszelkie próby pozbawiania papieża tych uprawnień podejmowane czy to na soborze w Bazylei, czy też przez polskie sejmy, są bezprawiem; świadczenia pierwszoroczne można by przeznaczyć na cele krajowe tylko za uprzednią zgodą papieża ${ }^{91}$.

Poglądy M. Dobrocieskiego w obronie annat rozwinął i uzupełnił Andrzej Li p s k i. Żył w latach 1572-1631, z wykształcenia prawnik, kanclerz koronny i biskup krakowski. Pozostawił kilka pism, wśród których należy tu wymienić: Decas quaestionum publicarum in quibus ecclesiastica iura et immunitas ecclesiastici status elucidantur (Cracoviae 1616; drugie wydanie tamże, 1632). Jest to szereg zagadnień z życia kościelnego, które autor rozstrząsa na tle współczesnych sobie stosunków. Wśród dziesięciu („decas”) kwestii A. Lipski na szóstym miejscu omawia sprawę annat pt. Statuta seu Constitutiones Regni de annatis Romanae Curiae denegandis an iuri sint consentaneae necne (s. 58). Już samo postawienie zagadnienia przesądza w pewnym sensie o zawartej w nim treści. Mianowicie autor stawia sobie za zadanie rozpatrzenie annat z punktu widzenia prawnego w świetle znoszących je konstytucji państwowych. Kanclerz koronny poddaje najpierw historycznej ocenie powstanie ustaw prze-

91, Z tego samego tedy słowa bożego kapłan najwyższy ma prawo na annaty, na pierwociny $\mathrm{z}$ biskupstw, które oszacował P. Bóg na dziesięcinę z dziesięcin. Którego prawa, gdy tego potrzeba było onych trudnych Kościoła Rzymskiego czasów, o których w kościelnej historyjej czytamy ojcowie święci poczęli być i do tego czasu są w używaniu [...] Dlatego ani koncylium Bazylejskie, które się bez głowy owszem przeciwko głowie odprawowało, odjąć tego papieżowi nie mogło, ani nasze konstytucye o tym pisane [...] do skutku nie przyszły jako te, które o cudzej rzeczy i ne tego, kto by jurysdykcyjej sejmowej nie podlegał pisane były. Owe przystojne staranie u Ojca św. o te rzeczy czynić potrzeba, a on gdy pozwoli łatwo rzecz będzie i duchownym tak ją tu dać na obronę Rzeczypospolitej, jako do Rzymu" (s. 26-n.). 
ciwannatowych mówiąc, że nie były one wyrazem ani woli króla, ani ogólnej zgody wszystkich stanów, lecz wynikały z lekkomyślności oraz braku zrozumienia dla tych spraw wśród stanu świeckiego ${ }^{92}$. Opinia ta rzuca światło na faktyczne źródło wrogości wobec annat, jakim była u nas szlachta. Zdaniem autora annaty mają uzasadnienie pośrednio w prawie Bożym, na równi z dziesięcinami oraz pierwocinami Starego Testamentu, bezpośrednio zaś w prawie kościelnym, i to zarówno pisanym jak zwyczajowym. Jako takie zaś nie mogą być naruszone żadną ustawą świecką. Podkreśla przy tym autor, że zamierzony cel wydanych ustaw sejmowych był zupełnie chybiony, gdyż faktyczne kwoty pieniężne pochodzące $\mathrm{z}$ annat były stosunkowo małe. Wyrażały się one za okres kilku lat w liczbie 10-20 tysięcy florenów (s. 58-61). A. Lipski kończy swoje wywody wezwaniem do zaprzestania nieuzasadnionych uskarżań i żalów na świadczenia annatowe ${ }^{93}$.

Prawie równocześnie z A. Lipskim, na szerszą jeszcze skalę, zajął się apologią annat starosta bydgoski Maciej Smogulecki. Na szczególną uwagę zasługuje on dlatego, że był to człwoek świecki, przedstawiciel stanu szlacheckiego (zmarł w r. 1617). Napisał on rozprawę pt. O exorbitancyach, które w tym wieku niektórzy Ich Mość P.P. świeccy nowi politycy stanowi duchownemu zadaj $q^{94}$. Jak wskazuje tytuł, autor omawia próby pozbawienia stanu duchownego statusu prawnego na wielu odcinkach. Między innymi dużo uwagi poświęca zagadnieniu annat. W sposób wszechstronny wykazuje, że wszelkie mieszanie się czynnika świeckiego do tej instytucji jest bezzasadne, a świadczenia te są prawomocne. Smogulecki nawiązuje przede wszystkim do poglądu sformułowanego już przez Dobrocieskiego i Lipskiego, że uprawnienie papieża do opłat annatowych ma ostatecznie oparcie w prawie Bożym na równi z pierwocinami oraz dziesięcinami Starego Testamentu. Następnie podkreśla, że doniosłej wagi motywem za annatami jest ich starodawność. Sięgają one wszak początków XIV w. Polska je zawsze uznawała. Gdy bowiem na soborze w Konstancji wyłoniła się debata w tej materii, delegacja polska wyraziła zgodę na annaty. Sobór zaś bazylejski nie może wchodzić w rachubę, zdaniem autora, gdyż był schizmatycki. Przeciwstawianie się więc annatom w tych warunkach byłoby wysoce niegodziwe, niezgodne $\mathrm{z}$ tradycyjnym duchem polskim i chrześcijańskim, odpowiadałoby natomiast nastrojom"rozsiewanym przez nowinkarzy oraz kacerzy"95. Autor Exorbitancyj analizuje dalej poszczególne konstytucje

92 „Extant de annatis tam superiorum quam recentium temporum, plures in volumine statutorum Regni leges a piissimis illis Regibus et Principibus, non tam illorum voluntate, aut communi sensu omnium ordinum Regni, quam importunitate atque temeritate quadam secularis status promulgate" (tamże).

93 „Optarem sane ut etiam tandem aliquando importunis ac sordidis istiusmodi quaerelis silentium imponatur, ne videlicet hac in parte, toti orbi christiano ingenii nostri morbus prodeamus" (tamże, s. 61).

${ }_{94}$ Wydane po raz pierwszy w Kaliszu w r. 1619, później zaś w Krakowie w 1632 r.

95 „Ponieważ tedy annaty od tak wiele lat w Polszcze zwyczajami dawnymi i konsensami Rzeczypospolitej potwierdzone są [...] niech każdy zacny i rozumny rozsądzi i owszem to exorbitancya 
sejmowe, wymierzone przeciw annatom i wykazuje ich bezprawność. Bezprawność ta polegała przede wszystkim na jednostronnym podejmowaniu decyzji w tych sprawach, co do których słuszne i nabyte prawa posiada papież, a zatem tylko z nim uzgodnione postanowienia mogłyby mieć jakieś znaczenie. Ponadto wymienione konstytucje zostały wydane wbrew woli duchownych, mających prawo głosu na sejmach. Wreszcie ściągają one na swoich autorów sankcje kanoniczne, przewidziane za naruszenie immunitetów kościelnych (tamże, s. 10-13, 16). Niemały nacisk kładzie dalej autor na motywy czysto ekonomiczne. Zwraca uwagę, że wartość finansowa wysyłanych z Polski annat jest stosunkowo niska. W porównaniu z Francją, gdzie jest dużo biskupstw dobrze uposażonych, w związku z czym dochody rosną w miliony, u nas biskupstw jest mało, a do tego ubogie. Kwoty annatowe w przeciętnym stosunku rocznym mogą tedy wynosić od $300-400$ złotych. Jest to zaś suma niższa od tej, jaką co roku wywozi z Polski do Wenecji przeciętny szlachcic polski, który udaje się tam „dla zbytków”. Annaty zaś nie idą „na zbytki”, lecz na potrzeby Stolicy Apostolskiej, wobec której spłacają nasz dług wdzięczności ${ }^{96}$. Omawiając ostatnią konstytucję sejmową z 1607 r., Smogulecki piętnuje wprowadzone przez nią drugie obok papieskich annaty dla skarbu państwa oraz dołączoną do niej sankcję egzekwowania ich z dóbr własnych. Jest to jego zdaniem skazywanie biskupów na biedę materialną, mające swe źródło w „posiewie wiary luterskiej" (s. 17 n.). Wreszcie autor stwierdza, że nasze ustawy przeciwannatowe nie były realizowane, lecz pozostały martwą literą, co jego zdaniem, należy tłumaczyć sprzecznością zachodzącą między nimi a katolicką świadomością polskiego społeczeństwa ${ }^{97}$.

Jakkolwiek w publikacjach polskich obrońców annat zachodzą zbieżności w doborze argumentów i ujmowaniu tematu, każdy z nich wnosi jednak coś własnego. Mikołaj Dobrocieski był pierwszy, który piórem podjął u nas obronę annat. Andrzej Lipski bardziej rozwinął, ugruntował i uzupełnił motywy obrończe. Maciej Smogulecki ujął tę sprawę najszerzej, a jako - w przeciwieństwie do poprzednich - człowiek świecki, zapewniał swym poglądom większą siłę oddziaływania.

zwyczaje ledwie nie zaraz z wiarą chrześcijańską przyjęte odmieniać, postanowienia tak wiele wieków świętobliwych przodków naszych wzruszać, z trybu dawnego i z kolei zwyczajnej wypaczać a nowe postanowienia za jadem dopiero kacerskim do Polski wniesione wszczynać i o tym co przodkowie nasi w osobie Namiestnika jego Panu Bogu oddawali u Judaszem przeklętym mówić ut quid perditio ista [...], poterat unguentum istud venumdari plusquam trecentis denariis et dari pauperibus, to jest na obronę Rzeczypospolitej obrócié” (tamże, s. 5).

${ }_{96}$ "Także kiedy by kto chciał we sto lat wiele $\mathrm{z}$ annat pożytku przyjdzie na każdy rok podle roku kładąc porachować... to annatom 300 albo $400 \mathrm{zl}$. uczyni zaledwie i dla takiej by warto fraszki wzruszać prawa wszystkie, odmieniać zastarzale zwyczaje, zwalczać na Rzeczypospolitą przekleństwa kościelne i niebłogosławieństwo Pańskie. Lada szlachcic dostatni na Wenecją, na grzechy, na marność rok po roku z Polski w cudze kraje więcej wywiezie, niż co się dotąd z annat do Rzymu dawało, wdzięczność pokazując tej tam najważniejszej St. Apostolskiej i matce naszej" (tamże, s. $20-21$ ).

97 „Dlatego katolicy nie dbali choć się takie konstytucye pisały, bo wiedzieli, że z tego ne miało być nic, gdyż się tak zawsze pisały, że egzekucyjej mieć nie mogły" (tamże, s. 20). 
Polscy rzecznicy obrony annat zgodnie więc podkreślali w swych pismach, że papież pobierając te świadczenia ma oparcie w prawie boskim, zwyczajowym i pisanym kościelnym, że żadna władza poza Stolicą Apostolską nie jest w mocy pozbawić Zwierzchnika Kościoła tych opłat, że skierowane przeciw pierwszorocznym opłatom konstytucje sejmów polskich są pozbawione znaczenia, że praktykę annatową należy dalej uważać za obowiązującą, tym bardziej że pochodzące z niej korzyści finansowe dla kraju są stosunkowo nieznaczne oraz, że przeciwne im ustawy nie są wyrazem ani woli króla, ani ogółu społeczeństwa, lecz hołdującej herezji szlachty. Przeciwstawiając się poglądom wrogim instytucji annat, polscy pisarze ukazali jej podstawy prawne w ogóle, a w szczególności w oprawie naszych polskich uwarunkowań. W ten sposób stali się obok nuncjuszy papieskich drugim czynnikiem, który w naszym kraju przyczynił się do zwycięskiego przetrwania annat w ogniu ich zwalczania.

Nie ulega wątpliwości, że oprócz działalności nuncjuszów papieskich i pisarzy, jako tych czynników, które działały bezpośrednio o utrzymanie praktyki annatowej, okolicznością sprzyjającą w tej akcji było ogólne tło stosunków polsko-rzymskich. Tak więc już w pierwszej połowie XV w., gdy na soborze w Konstancji inne kraje mocno atakowały instytucję annat, delegację polską pochłaniały o wiele ważniejsze dla kraju problemy związane ze sprawą krzyżacką $^{98}$. Następnie druga połowa XV oraz pierwsze dziesiątki XVI w. to okres, w którym na czoło załatwianych w Rzymie spraw wysunęła się prowizja polskich beneficjów. Papieże czynili w tym zakresie ustępstwa zarówno na rzecz królów, ubiegających się o obsadę stanowisk swoimi kandydatami, jak również na rzecz biskupów, którym przyznawali tzw. alternatywę miesięcy, tj. prawo prowizji w określonych miesiącach roku. Wobec tych prowizyjnych ustępstw Stolicy Apostolskiej tak król jak szlachta nie stawiali postulatu zniesienia annat na ostrzu miecza. Zresztą trzeba pamiętać, że osiągnięcia prowizyjne zwyczajnych kolatorów (tj. biskupów) były równocześnie pośrednimi sukcesami na polu annat, jeśli idzie o beneficja niższe, gdyż te płacono jedynie $\mathrm{z}$ beneficjów nadawanych przez papieży. Dalszą cechą stosunków polsko-rzymskich były ustępstwa finansowe papieży na rzecz naszego kraju. Tak np. Juliusz II odstąpił w 1505 r. królowi polskiemu Aleksandrowi świętopietrze z okresu dziesięciu lat dla odbudowy zniszczonego wojnami kraju'00. Na dalszych dziesięć lat przedłużył ten przywilej Leon X (1512-1521). Oprócz tego Leon X wspierał polskiego króla ubocznie, ogłaszając po 1515 r. kilka odpustów jubileuszowych w Polsce i na Litwie, które dawały poważną sumę około 15000 du-

${ }^{98}$ L. Win ow ski, Annaty, Lublin 1967 (maszynopis; hasło przygotowane do Encyklopedii katolickiej).

${ }_{99}$ Acta Alexandri Regis Poloniae et M. D. Lit. (1501-1506), ed. F. P a pé e, Kraków 1927, s. 282 (n. 167); Z, W o j ci e c h ow s k i, Zygmunt Stary 1506-1548, Warszawa 1946, s. 138.

${ }_{100}$ VMPL' 2 s. 303 (n. 327). 
katów rocznie ${ }^{101}$. Papież Paweł III (1534 - 1539) dwukrotnie darował królowi polskiemu poważną sumę pieniężną: raz 10000 dukatów, drugi raz 100000 skudów (tj. ok. 12000 dukatów) z polskich należności annatowych ${ }^{102}$. Wyliczone przykłady finansowych koncesji dawały z jednej strony podstawę Stolicy Apostolskiej do nieustępliwości w sprawie annat, z drugiej zaś - przynajmniej chwilowo lagodziły wrogie do nich nastawienie opozycji polskiej ${ }^{103}$. Trzecią wreszcie właściwością stosunków polsko-rzymskich w okresie nasilenia walki $\mathrm{z}$ annatami była wspólna orientacja wobec zagrażającej Europie potęgi tureckiej. Królowie polscy doznawali na tej podstawie u papieży pełnego poparcia, nie tylko moralnego, lecz także finansowego ${ }^{104}$. Polska opinia polityczna w oparciu o tę przypisywaną krajowi misję obrony przeciwtureckiej wysuwała tym większe roszczenia do annat. Wobec jednak pryncypialnej postawy Stolicy Apostolskiej nie chciała jednostronnie ograniczać uprawnień finansowych papieży, lecz dążyła do uzyskania ich zgody. Wspomniany układ stosunków pomiędzy Polską i Stolicą Apostolską nie przynosił wzajemnych zadrażnień i bez wątpienia nie mało się przyczynil, że opisane powyżej czynniki obrony annat mogły były odegrać pozytywną rolę.

Na przełom XVIII i XIX w. przypadło de facto załamanie się dotychczasowego systemu annatowego. We Francji opłaty te zostały obalone przez Rewolucję w 1789 r. ${ }^{105}$ Ostatecznie na początku XIX w. biskupi oraz arcybiskupi francuscy zaczęli z okazji promocji przekazywać Kurii Ŕzymskiej niewielką kwotę tytułem pokrycia kosztów za sporządzenie bulli nominacyjnej ${ }^{106}$. Na terenie Niemiec wymiar taks serwicjalnych biskupów został tak zmniejszony, że nie można ich już uważać za te same świadczenia annatowe. Były to tylko ich pozostałości. Np. Wrocław mający przedtem taksę 4000 florenów miał obecnie

${ }^{101}$ L. Kol ank owski, Sprawy polskie przed Stolica Apostolska, „Kwartalnik Historyczny” 22:1908 s. 323.

102 B. Dembiński, jw., s. $90-93$.

103 Prawdopodobnie tym ustępstwom należy przypisać ostanie się annat w Polsce w bardzo krytycznych latach: $1537,1544-1548$.

${ }^{104}$ L. Kolankowski, jw., s. 323; Historia Polski, jw., Warszawa 1957, s. 182.

105 F. Mahon de Monaghan, jw., s. 318-319.

106 A. Puglie s e utrzymuje (jw. S. 51), że biskupi francuscy do tej małej taksy dodawali annaty, obliczane najpierw na około jedną czwartą, a później na jedną trzecią rocznych dochodów. W każdym razie należy zaznaczyć, że sprawa annat we Francji miała już odtąd charakter raczej nieoficjalny. Potwierdzeniem ubocznym tego są dziewiętnastowieczne konkordaty francuskie, które materię zarówno wymienionych taks jak i annat pomijają całkowitym milczeniem; - zob. Raccolta di concordati su materie ecclesiastiche tra Santa Sede e le Autoritâ Civili, ed. A. Me r c a ti, t. 1, Tipografia Poliglotta Vatricana 1954, s. 561-565, 579-581 (ma tych bowiem miejscach powinna się znaleźć materia annat). 
1166 florenów. Płatność ta dla arcybiskupstwa Kolonii spadła z 10000 na 1000 florenów ${ }^{107}$.

W ten sposób trzeba przyjąć, że właściwe, tzn. pierwotne annaty zanikły, a na ich miejsce zostały wprowadzone pewnego rodzaju ta k s y a n c e la r y jne. Stolica Apostolska zaczęła je traktować wyłącznie administracyjnie oraz indywidualnie. Należy to przypisać postępowi laicyzacji stosunków w dziewiętnastowiecznych państwach oraz procesowi rozdziału między Kościołem a Państwem, jaki w tym czasie systematycznie narastał ${ }^{108}$. W tym świetle jest rzeczą zrozumiałą, że i Kodeks prawa kanonicznego z r. 1917 pozostawia poza obrębem swego ustawodawstwa świadczenia na rzecz Kurii Rzymskiej od kandydatów na beneficja, zarówno większe jak mniejsze. Formę tych świadczeń zaczęto po prostu określać oddzielnie w stosunkach z poszczególnymi beneficjatami. Instrukcja Datarii Apostolskiej z 1 stycznia 1942 r. podaje dyrektywy dla ordynariuszów dotyczące podań o nadanie przez Stolicę Apostolską zarezerwowanych jej beneficjów niekonsystorialnych. Między innymi Dataria żąda podania rocznych dochodów odnośnych stanowisk. Jest to jakieś dalekie echo annat $\mathrm{z}$ jednej strony oraz najprawdopodobniej zamiar oparcia wymiaru taksy prowizyjnej na podstawie dochodów rocznych $\mathrm{z}$ drugiej ${ }^{109}$.

Kanon 1482 Kodeksu prawa kanonicznego z r. 1917 odnosił się do tak zwanych półannat („media annata”). Mianowicie wedle kan. 1482 tego Kodeksu należało pozostawić w mocy „półannaty”, o ile gdzieś istniały, w myśl partykularnych statutów oraz miejscowych zwyczajów. Otóż trzeba z naciskiem podkreślić, że te półannaty nie miały nic wspólnego z dawnymi annatami papieskimi. Chodziło tu mianowicie o różne partykularne przepisy, tak zwyczajowe jak pisane, których mocą z beneficjów niższych pewna część, a przeważnie połowa dochodów z okresu wakansu, przypadała „fabryce kościoła” (tj. jego utrzymaniu) lub szła na inne zbożne cele. Taki sens tamtego kanonu nie ulega najmniejszej wątpliwości. Potwierdzają go bowiem źródła, na których się opie$\mathrm{ra}^{110}$. W ich świetle staje się jasne, że przez „półannaty” ustawodawca Kodeksu z 1917 r. rozumiał część dochodów jednego roku, przeważnie zaś połowę, które z okresu wakansu beneficjów były przekazywane przez nowego posiadacza danego urzędu na utrzymanie („fabrykę”) kościoła. Tak pojęte półannaty

${ }^{107}$ G. Philips, jw., t. 5 s. 598.

108 Stąd też np. w Stanach Zjednoczonych Ameryki Północnej, gdzie w XIX w. Kościół od razu był zmuszony przyjąć prawny status rozdziału od państwa, annaty nie zostały w ogóle wprowadzone; - zob. Ch. Augu st in e, A commentary on the new Code of Canon Law, t. 6, St. Louis 1921, s. 541.

109 Instructio de observandis a Remmis Ordinariis quum ab Apostolica Dataria collationem petant beneficiorum non consistorialium, quae ad normam iuris Apostolicae Sedi sint reservata vel devoluta „Acta Apostolicae Sedis” 34:1942 s. 313-318.

110 'Źródłami powolanymi do tego kanonu są przede wszystkim: 14. kanon 24. sesji soboru trydenckiego De reformatione; konstytucja papieża Piusa V Durum nimis, wydana 1 czerwca $1570 \mathrm{r}$. Zob. też: Canones et decreta sacrosancti oecumenici Concilii Tridentini, Romae 1904, s. 194-195; Codicis iuris canonicifontes, ed. card. P. G a s p a ri i, t. 1, Romae 1923, s. 240 (n. 134), s. 505-508 (n. 259). 
nie miały nic wspólnego $\mathrm{z}$ annatami papieskimi, które były świadczeniami zupełnie oddzielnej kategorii ${ }^{111}$. Błędnie zatem komentowali wspomniany kanon ci autorzy, którzy w jego treści chcieli zamknąć dawne annaty papieskie ${ }^{112}$. Kodeks prawa kanonicznego papieża Jana Pawła II z r. 1983 w ogóle już nie wspomniał ani o dawnych annatach, ani o półannatach. W ten sposób jedno i drugie zagadnienie stało się już wyłącznie przedmiotem historii.

\section{DIE KONTROVERSE ÜBER DIE ANNATEN IN POLEN}

\section{Zusamenfassung}

Vom 13. bis 19. Jh. bezog der Apostolische Stuhl die nach Jahreseinnahmen berechneten Abgaben von den Kirchenämtern, die durch den Papst selbst auferlegt wurden. Gegen die Annaten entstand ein Widerspruch von Seiten der lokalen Faktoren, sowie der Staatsherscher, der Geistlichkeit, des Adelstands, der Schriftsteller. Jene Opposition erweckte wiederum die Verteidigung der erwähnten Annaten ein Prozeß, der in den verschiedenen Ländern einen eigenen Verlauf hatte.

Die Auseinandersetzung über die Annaten in Polen seit 15. bis $17 \mathrm{Jh}$. ist in zwei Kapiteln vorgestellt: (1) die Bekämpfung und (2) die Verteidigung der Annaten. Beide hatten in Polen ihr eigenes Spezifikum, und zwar war die Bekämpfung dort nicht so radikal wie z. B. in Frankreich oder in Deutschland zur gleichen Zeit. In Polen nämlich verlangte man nicht die Aufhebung, sondern eine Verminderung der Annaten, damit ein Teil davon das durch die vielen Kriege ruinierte Land unterstützen könnte. Die Päpste hatten ihrerseits Verständnis gezeigt, und auf diesem Gebiet wurde zwischen dem Apostolischen Stuhl und den polnischen Königen mehrere Abkommen getroffen. Z. B. hat Papst Paul III. (1534 -1549) dem polnischen König Sigismund dem Alten zweimal eine beträchtliche Geldsumme übertragen. Dagegen wurden die finanziellen Rechte der Kirche durch die polnische Könige respektiert.

111 Por. B. Ojetti, Synopsis rerum moralium et iuris pontificii, t. 2, Romae 1911, s. 2590 2593.

${ }^{112}$ E. Eich mann, K. Mörsdorf, Lehrbuch des Kirchenrechts auf Grund des Codex Iuris Canonici, t. 2, Paderborn 1953, s. 455; P. H. Jo n e, Commentarium in Codicem Iuris Canonici, t. 2, Paderborn 1954, s. 602. Trafnie natomiast skomentował tekst kanonu 1482 C. M. Co r o n a ta: Institutiones iuris canonici, t. 2, Taurini 1948, s. 432. 